\title{
Synthesis and analytical properties of a novel columnar metallomesogenic polymer
}

\author{
Chuen-Ying Liu*, Jian-Lian Chen, Chia-Chann Shiue, Kung-Tien Liu \\ Department of Chemistry, National Taiwan University, Taipei, Taiwan
}

Received 14 June 1999; received in revised form 12 August 1999; accepted 24 August 1999

\begin{abstract}
A metallomesogenic side-chain polymer with copper carboxylato discotic units in stacks prepared by covalent bonding of 14-pentadecenoic acid, stearic acid and poly(methylhydrosiloxane) is described. The physico-chemical and thermal properties of both monomeric and polymeric metallomesogens were determined by elemental analysis, IR, polarizing optical microscopy, thermal gravimetric analysis and differential scanning calorimetry. The polymeric states showed a discotic lamellar phase at $50-95^{\circ} \mathrm{C}$ and an ordered discotic hexagonal phase at $95-200^{\circ} \mathrm{C}$. By dynamic coating, the metallomesogenic polymer was crosslinked to the capillary wall via benzoyl peroxide. The wall-coated capillary columns $(15 \mathrm{~m} \times 0.25 \mathrm{~mm}$ I.D.) were used for the separation of phenols. Factors affecting the retention and the sample selectivity were examined. Van ' $t$ Hoff plots as a function of temperature indicated that phase transitions were occurring. Thermodynamic properties of the analytes in this system were also studied. For the determination of a mixture of 3-aminophenol, 2-chlorophenol, 2-nitrophenol, 4-nitrophenol, $o$-methylphenol, $m$-methylphenol, $p$-methylphenol, 2,4-dichlorophenol, 2,4-dimethylphenol, 2,4-dinitrophenol, 2,4,6-trichlorophenol, 2,4,6-trimethylphenol, 4-bromophenol, 3-methyl-4-chlorophenol, pentachlorophen$\mathrm{ol}$, and unsubstituted phenol, the calibration graphs for most phenols were linear over the range of $10-1000 \mu \mathrm{g} \mathrm{ml}^{-1}$ and the mass detection limits were in the ng range based on three times standard deviation of seven measurements of the lowest peak that could be detected. (C) 1999 Elsevier Science B.V. All rights reserved.
\end{abstract}

Keywords: Stationary phases, GC; Metallomesogenic polymer; Phenols

\section{Introduction}

Liquid crystals have found widespread use as stationary phases in gas chromatographic applications due to the benefits of coupling the usual analytical strengths of gas chromatography with the unique structure and shape selectivity properties of the liquid crystalline phase. Interaction of solutes with the orientational order provided by the aniso-

*Corresponding author. Tel.: +886-2-23630231; fax: +886-223636359. tropy of the liquid crystal stationary phase allows for the effective and selective separation of positional and geometric isomers. This remarkable solute structural discrimination is especially important for the separation of isomers that have similar physical properties and thus cannot be conveniently separated on conventional capillary columns that mainly differentiate on the basis of boiling point/molecular weight or polarity differences.

In metallomesogens, as with organic mesogens, molecular shape and intermolecular forces play an important role. The presence of one or more metals 
opens many exciting possibilities, because the coordination of metal ion may lead to properties not easily found in organic mesogens [1]. In contrast to the about 400 papers describing the use of organic mesogens in GC, there have been few publications on the use of metallomesogens as stationary phases of GC [2-8]. The use of a metallomesogen for GC was reported for the first time when Takayanagi et al. reported that even though copper stearate showed low stability at high temperature, the solid stationary phase was efficient and selective [2-4]. Berdague et al. described a gas chromatographic study of the thermal and analytical properties of a nematic liquid crystal and its cupric complex [5]. Liu and coworkers reported that both monomeric and polymeric 4-decanoxydithiobenzoic acid metal complexes could be used successfully for the separation of dialkyl sulfides, polyaromatic hydrocarbons and phenols [68].

The analytical determination of phenols is necessary because of their toxicity and their widespread use in industry. Nowadays, the most widely used analytical technique for the determination of phenols is gas chromatography, because of its high sensitivity and resolving power. GC of underivatized phenols using capillary columns with conventional phase is difficult however, and in particular nitrophenols tend to tail, even when using highly deactivated columns [9]. To avoid this disadvantage, phenols are derivatized to give less polar compounds with better chromatographic characteristics.

In a previous paper, rod-like metallomesogens of both 4-decanoxydithiobenzoic acid metal complexes coated on Chromosorb W AW/DMCS and metal complexes of 4-(dec-9'-en-1'-oxy)dithiobenzoate siloxane polymer coated on capillary wall were used as stationary phases for the separation of underivatized phenols [8]. Satisfactory results were obtained for the usage. To date, reported applications with regard to stationary phases based almost exclusively on calamitic liquid crystals, only a few examples using discotic stationary phases [10-12]. Since differences were found for the separation of xylenes in the behavior of disc-like and rod-like liquid crystalline stationary phases, in this work, a novel disclike metallomesogenic polymer has been synthesized and coated on the capillary wall, in order to determine what differences occur between disc-like and rod-like phases for the gas chromatographic separation of phenols.

\section{Experimental}

\subsection{Apparatus}

Elemental analyses were carried out with a Perkin Elmer elemental analyzer (model 2400), provided by the Elemental Analyses Service Center of NSC at the National Taiwan University. IR spectra were obtained on a Bio-Rad spectrophotometer (model FTS40). Phase transitions were studied by differential scanning calorimetry (DSC) on a TA-2920 apparatus, operating through first heating, cooling and second heating ranging from room temperature to $250^{\circ} \mathrm{C}$ at heating rate of $10^{\circ} \mathrm{C} \mathrm{min}^{-1}$ under an $\mathrm{N}_{2}$ flow $\left(100 \mathrm{ml} \mathrm{min}^{-1}\right)$. A TA-2950 type thermogravimetric analyzer was used for the measurement of sample thermal stability under a continuous $\mathrm{N}_{2}$ flow $\left(60 \mathrm{ml} \mathrm{min}^{-1}\right)$ at a rate of temperature rise of $10^{\circ} \mathrm{C} \mathrm{min}^{-1}$. Hot stage polarized microscopy was carried out with a Olympus BX-50 microscope equipped with a Unkam TMS-92. The gas chromatography used throughout for column evaluation was a Shimadzu Model 17A, equipped with a capillarycolumn split-injection system and an FID detector. Nitrogen was used as the carrier gas. Chromatograms were plotted on a Shimadzu CR-6A Chromatopac integrator.

\subsection{Reagents and chemicals}

Most chemicals were analytical reagent grade from Merck (Darmstadt, Germany). Purified water $(18 \mathrm{M} \Omega \mathrm{cm})$ from a Milli-Q water purification system (Millipore, Bedford, MA, USA) was used to prepare all solutions. 4-Chlorobutene, 11-bromoundecanoic acid and Michler's ketone $\left[\left(\mathrm{CH}_{3}\right)_{2} \mathrm{~N}-\mathrm{Ph}-\right.$ $\mathrm{COPhN}\left(\mathrm{CH}_{3}\right)_{2}$ ] (TCI, Tokyo, Japan); methylmagnesium chloride, potassium hydroxide, magnesium turnings, toluene and tetrahydrofuran (Merck); dilithium tetrachlorocuprate (Aldrich, Milwaukee, WI, USA); chloroplatinic acid and benzophenone (Janssen, Belgium); as well as poly(methylhydrosiloxane) (PS 122, $M_{\mathrm{n}}=4500 \sim 5000$ ) (Petrach systems, Bristol, 
PA, USA), were purchased from the indicated sources. All liquid reagents and solvents used in moisture-sensitive reactions were distilled and collected over type $4 \AA$ molecular sieves. All solid materials used in moisture-sensitive reactions were dried at $110^{\circ} \mathrm{C}$ for $24 \mathrm{~h}$ prior to the experiment.

Analytes including 3-aminophenol (b.p. $164^{\circ} \mathrm{C}$; length to breadth ratio 1.157) (Fluka, Switzerland), 2-chlorophenol $\left(174^{\circ} \mathrm{C} ; \quad 1.106\right), \quad$ 2-nitrophenol (214 $\left.{ }^{\circ} \mathrm{C} ; 1.024\right), 2,4$-dichlorophenol $\left(210^{\circ} \mathrm{C} ; 1.265\right)$, 2,4-dimethylphenol $\quad\left(211^{\circ} \mathrm{C}, \quad 1.271\right), \quad 2,4,6$-trimethylphenol $\left(220^{\circ} \mathrm{C}, 1.063\right), 2,4,6$-trichlorophenol $\left(246^{\circ} \mathrm{C}\right.$; 1.146), 3-methyl-4-chlorophenol $\left(235^{\circ} \mathrm{C}\right.$; $1.110)$, 4-bromophenol $\left(235^{\circ} \mathrm{C}, 1.458\right)$, pentachlorophenol $\left(310^{\circ} \mathrm{C}, 1.182\right)$ (TCI, Tokyo, Japan), $o$ methylphenol $\left(191^{\circ} \mathrm{C}, \quad 1.003\right), \quad m$-methylphenol $\left(203^{\circ} \mathrm{C}, 1.183\right), \quad p$-methylphenol $\left(202^{\circ} \mathrm{C}, 1.625\right)$ (Wako, Japan), 4-nitrophenol $\left(279^{\circ} \mathrm{C}, 1.591\right)$, unsubstituted phenol $\left(180^{\circ} \mathrm{C}, 1.280\right)$ (Merck, Darmstadt, Germany) and 2,4-dinitrophenol (1.224) (Janssen, Belgium) were obtained from the indicated sources.

\subsection{Synthesis of copper stearate [13]}

An admixture of 0.1 mol sodium stearate $(30.65$ g) and $0.05 \mathrm{~mol}$ copper sulfate $(7.98 \mathrm{~g})$ were both dissolved in a ethanol-aqueous solution, but with a volume of $300 \mathrm{ml}, 70 \%$ and $200 \mathrm{ml}, 50 \% \mathrm{v} / \mathrm{v}$, respectively, and then stirred for $4 \mathrm{~h}$ at $60^{\circ} \mathrm{C}$. After standing overnight, the filtrate was discarded and the residue was extracted twice with $n$-heptane, producing a bluish green product, copper stearate $(\mathrm{CuSt})$. IR: $\rho_{\left(\mathrm{CH}_{2}\right)}=720 \quad \mathrm{~cm}^{-1}, \quad v_{(\mathrm{COO}-) \mathrm{symm}}=1316 \quad \mathrm{~cm}^{-1}$, $\delta_{\left(\mathrm{CH}_{3}\right) \mathrm{symm}}=1395 \mathrm{~cm}^{-1}, \quad \delta_{\left(\mathrm{CH}_{3}\right) \text { asymm }}=1450 \mathrm{~cm}^{-1}$, $\delta_{\left(\mathrm{CH}_{2}\right) \text { symm }}=1485 \mathrm{~cm}^{-1}, \quad v_{(\mathrm{COO}-) \text { asymm }}=1587 \mathrm{~cm}^{-1}$, $v_{\left(\mathrm{CH}_{2}\right) \mathrm{symm}}=2850 \quad \mathrm{~cm}^{-1}, \quad v_{\left(\mathrm{CH}_{2}\right) \text { asymm }}=2917 \quad \mathrm{~cm}^{-1}$, $v_{\left(\mathrm{CH}_{3}\right) \text { asymm }}=2957 \mathrm{~cm}^{-1}$. Anal. Calc. For $\mathrm{Cu}_{2}\left(\mathrm{C}_{17} \mathrm{H}_{35} \mathrm{COOH}\right)_{4}$ (CuSt): C (\%) 68.58, H (\%) 11.19; found: C 67.91, H 11.45 .

\subsection{Synthesis of the metallomesogenic polymer}

The polymeric liquid crystal phase was prepared by the following procedures:

Magnesium turnings $(0.59 \mathrm{~g}, 0.024 \mathrm{~mol})$ were placed in a two-neck round-bottom flask equipped with an additional funnel, a reflux condenser and a stirrer. 4-Chloro-/-butene $(2.17 \mathrm{~g}, 0.024 \mathrm{~mol})$ in dry tetrahydrofuran $(10 \mathrm{ml})$ was added dropwise to the reaction mixture which was under a nitrogen atmosphere. A small crystal of iodine was added as the catalyst. Any excessive heating was avoided with an ice bath. The reaction was continued until the brownish yellow mixture turned colorless to form 3-butenylmagnesium chloride (Grignard reagent I).

In another flask, 11-bromoundecanoic acid (6.36 $\mathrm{g}, 0.024 \mathrm{~mol})$ in dry THF $(2.8 \mathrm{ml})$ was added dropwise to methylmagnesium chloride $(8.6 \mathrm{ml}$ of $2.7 \mathrm{M})$ in THF $(30 \mathrm{ml})$ under nitrogen at $-20^{\circ} \mathrm{C}$. At the cessation of gas evolution, a coupling agent, dilithium tetrachlorocuprate $(4.6 \mathrm{ml}$ of $0.1 \mathrm{M})$ was added to the solution, followed then by the addition, over a 15 min period, of Grignard reagent (I) in THF. The mixture was stirred at $-20^{\circ} \mathrm{C}$ until a negative Gilman test was observed and then poured into an admixture of dilute sulfuric acid $(0.1 \mathrm{M})$ benzene. After removal of the aqueous solution, the product in the benzene layer was extracted into saturated aqueous potassium hydroxide. This was acidified, and the liberated product collected in benzene. Distillation under reduced pressure yielded an ivory-white product, 14-pentadecenoic acid, compound II. IR: $\rho_{\left(\mathrm{CH}_{2}\right)}=721 \mathrm{~cm}^{-1}, \delta_{(\mathrm{HC}=\mathrm{C}) \text { out of plane }}=$ $909.5 \mathrm{~cm}^{-1}, v_{(\mathrm{C}-\mathrm{O})}=1285 \mathrm{~cm}^{-1}, \delta_{(\mathrm{OH})}=1413 \mathrm{~cm}^{-1}$, $\delta_{(\mathrm{HC}=\mathrm{C}) \text { in plane }}=1416 \quad \mathrm{~cm}^{-1}, \quad \delta_{\left(\mathrm{CH}_{2}\right)}=1467 \quad \mathrm{~cm}^{-1}$, $v_{\text {(C) })}=1720 \quad \mathrm{~cm}^{-1}, \quad v_{\left(\mathrm{CH}_{2}\right) \mathrm{symm}}=2853 \quad \mathrm{~cm}^{-1}$, $v_{\left(\mathrm{CH}_{2}\right) \text { asymm }}=2924 \mathrm{~cm}^{-1}$. Anal. Calc. For $\mathrm{C}_{14} \mathrm{H}_{27} \mathrm{COOH}$ : C (\%) 75, $\mathrm{H}(\%)$ 11.6; found: C 75.4, H 11.6.

Poly(methylhydrosiloxane) $(0.31 \mathrm{~g}, 0.063 \mathrm{mmol})$ and compound II $(1.2 \mathrm{~g}, 5 \mathrm{mmol})$ in dry toluene $(15.5 \mathrm{ml})$ were placed into a round bottom flask. Chloroplatinic acid $\left(\mathrm{H}_{2} \mathrm{PtCl}_{6} \cdot x \mathrm{H}_{2} \mathrm{O}\right)(50 \mathrm{ppm}, \mathrm{w} / \mathrm{v})$ in 2-propanol $(0.5 \mathrm{ml})$ was added as catalyst. The reaction mixture was stirred under nitrogen and heated at $50^{\circ} \mathrm{C}$. The heating was continued for $48 \mathrm{~h}$. The reaction extent can be monitored from IR spectra $\left(2169 \mathrm{~cm}^{-1}\right)$ by the amount of $\mathrm{Si}-\mathrm{H}$ remaining in the reaction mixture. When the $\mathrm{Si}-\mathrm{H}$ band could no longer be detected, the reaction was complete. The product is compound III $(\mathrm{P}-\mathrm{L})$. IR: $\rho_{\left(\mathrm{CH}_{2}\right)}=723 \mathrm{~cm}^{-1}, v_{(\mathrm{Si}-\mathrm{O})}=1100 \mathrm{~cm}^{-1}, v_{(\mathrm{C}-\mathrm{O})}=1270$ $\mathrm{cm}^{-1}, \quad \delta_{\left(\mathrm{CH}_{3}\right) \mathrm{s}}=1392 \mathrm{~cm}^{-1}, \quad \delta_{(\mathrm{OH})}=1416 \mathrm{~cm}^{-1}$, $\delta_{\left(\mathrm{CH}_{3}\right) \text { asymm }}=1441 \mathrm{~cm}^{-1}, \quad \delta_{\left(\mathrm{CH}_{2}\right) \mathrm{symm}}=1463 \mathrm{~cm}^{-1}$, 
$v_{\text {(CO) }}=1710 \mathrm{~cm}^{-1}, v_{\left(\mathrm{CH}_{2}\right) \mathrm{symm}}=2854 \mathrm{~cm}^{-1}, v_{(\mathrm{OH})}=$ $2960 \mathrm{~cm}^{-1}, v_{\left(\mathrm{CH}_{2}\right) \text { asymm }}=2926 \mathrm{~cm}^{-1}$. Elemental analysis (EA) for III is C (\%) 54.78, $\mathrm{H}(\%) 9.55$.

To compound III, sodium hydroxide $(0.1 \mathrm{M}, 50$ $\mathrm{ml})$ was added. Copper sulfate $(0.95 \mathrm{~g})$ and sodium stearate $(1.53 \mathrm{~g})$ were then added sequentially and reacted at $60^{\circ} \mathrm{C}$ with stirring for $4 \mathrm{~h}$. The final product $(\mathrm{P}-\mathrm{LCuSt})$ was recrystallized from $n$-heptane and dichloromethane sequentially. IR: $\rho_{\left(\mathrm{CH}_{2}\right)}=$ $723 \mathrm{~cm}^{-1}, v_{(\mathrm{Si}-\mathrm{O})}=1116 \mathrm{~cm}^{-1}, v_{(\mathrm{C}-\mathrm{O})}=1273 \mathrm{~cm}^{-1}$, $v_{\text {(COO-) } \mathrm{symm}}=1419 \quad \mathrm{~cm}^{-1}, \delta_{\left(\mathrm{CH}_{3}\right) \text { asymm }}=1440 \quad \mathrm{~cm}^{-1}$, $\delta_{\left(\mathrm{CH}_{2}\right) \mathrm{symm}}=1465 \mathrm{~cm}^{-1}, \quad v_{(\mathrm{COO}-) \text { asymm }}=1589 \mathrm{~cm}^{-1}$, $v_{\left(\mathrm{CH}_{2}\right) \mathrm{symm}}=2855 \mathrm{~cm}^{-1}, v_{\left(\mathrm{CH}_{2}\right) \text { asymm }}=2920 \mathrm{~cm}^{-1}$. EA for $\mathrm{P}-\mathrm{LCuSt}$ is $\mathrm{C}(\%) 50.84, \mathrm{H}(\%) 8.93$.

\subsection{Capillary column preparation}

Deactivated fused-silica capillaries $(15 \mathrm{~m} \times 0.25$ mm I.D., Restek, Bellefonte, PA) were first rinsed with methanol and dichloromethane $(5 \mathrm{ml}$ each) sequentially. The capillaries were then conditioned at $250^{\circ} \mathrm{C}$ with a gentle flow of nitrogen for about $2 \mathrm{~h}$ and coated dynamically with P-LCuSt. The column rinsing kit (Restek, Bellefonte, PA) was used as the coating reservoir. One end of the fused silica was connected to the reservoir. The other end was connected to a buffer capillary column $(5 \mathrm{~m} \times 0.5$ mm I.D.) with a glass connector. A solution containing metallomesogenic polymer $(0.15 \mathrm{~g} \mathrm{P}-\mathrm{LCuSt})$ in dichloromethane $(5 \mathrm{ml})$ and benzoyl peroxide (3\% $\mathrm{w} / \mathrm{w}$ of the linear polymer) was introduced into the capillary (ca. 1/4 column length), and then forced through the whole column at $1 \sim 2 \mathrm{~cm} \mathrm{~s}^{-1}$ with nitrogen. When the plug had exited the column, the pressure was increased to 40 p.s.i., and the solvent allowed to evaporate slowly (over at least $1 \mathrm{~h}$ ), in order to ensure that the capillary wall surface was coated smoothly and uniformly. After coating, the columns were then placed in the nitrogen-purged oven of a gas chromatograph. The temperature was raised from 40 to $190^{\circ} \mathrm{C}$ at a heating rate of $3^{\circ} \mathrm{C}$ $\min ^{-1}$. The heating was continued for $6 \mathrm{~h}$, during which time the cross-linking took place. Then the column was rinsed with dichloromethane $(5 \mathrm{ml})$ to remove any traces of unreacted material and further purged with nitrogen for about $15 \mathrm{~min}$ until a constant stable base-line was obtained.

\section{Results and discussion}

\subsection{Characterization of the synthesized metallomesogens}

The reactions involved in the preparation of metallomesogens are shown in Fig. 1. First of all, a long-chain carboxylic acid containing an omega vinyl group was synthesized. Poly(methylhydrosiloxane) was then reacted with the alkenoic acid. The product is $\mathrm{P}-\mathrm{L}$. Copper sulfate and sodium stearate were introduced into the $\mathrm{P}-\mathrm{L}$ to give a mixed ligand metallomesogen $(\mathrm{P}-\mathrm{LCuSt})$.

The liquid crystal properties of $\mathrm{CuSt}$ and $\mathrm{P}-\mathrm{LCuSt}$ were characterized via the techniques of polarized light microscopy and calorimetric investigation (Fig. $2)$. On first heating, there is an endothermic crystal transition for CuSt at $116^{\circ} \mathrm{C}$ with a $\Delta H$ of $124.8 \mathrm{~J}$ $\mathrm{g}^{-1}$. However, if the sample is then cooled from $250^{\circ} \mathrm{C}$, we obtain two exothermic peak at $108^{\circ} \mathrm{C}$ and $41^{\circ} \mathrm{C}$ with $\Delta H$ of only $-52.56 \mathrm{~J} \mathrm{~g}^{-1}$ and $-13.48 \mathrm{~J}$ $\mathrm{g}^{-1}$, respectively. This must mean that there is a different phase at the lower temperature. On second heating, the same phenomena with two transition temperatures but slightly higher than the previous ones were obtained and endothermal peaks were obtained probably corresponding to the transition from a solid crystal to discotic lamellar $\left(\mathrm{D}_{\mathrm{L}}\right)$ at $54^{\circ} \mathrm{C}$ and that from the $\mathrm{D}_{\mathrm{L}}$ to discotic hexagonal ordered phase $\left(D_{\text {ho }}\right)$ at $125^{\circ} \mathrm{C}$. Giroud-Godquin et al. $[13,14]$ investigated systematically the mesophase of copper carboxylates, $\mathrm{Cu}_{2}\left(\mu-\mathrm{O}_{2} \mathrm{CC}_{n} \mathrm{H}_{2 n+1}\right)_{4}(n=12-22)$ as ordered hexagonal columnar-discotic texture $\left(\mathrm{D}_{\mathrm{ho}}\right)$ and found only a transition to the thermotropic columnar mesophase at about $110-120^{\circ} \mathrm{C}$ for each compound of a series $n=12$ to $n=22$ on the basis of DSC, optical microscopy, and X-ray diffraction data. In this work, the lower transition temperature might be the discotic lamellar phase $\left(D_{L}\right)$ of $\mathrm{Cu}(\mu-$ $\left.\mathrm{O}_{2} \mathrm{CC}_{17} \mathrm{H}_{35}\right)_{2}$ characterized by a tilt of the alkyl chains to the copper-carboxylato square planar layer as 1,3-bis ( $p$-substituted-phenyl)- $\beta$-diketonate does [15]. The results of optical microscopy also gave two transition temperatures. In a similar way, the liquid crystal properties of the metallomesogenic polymer, $\mathrm{P}-\mathrm{LCuSt}$ were also investigated. The thermal properties of CuSt and P-LCuSt are summarized in Table 1. A significant variation in phase transition tempera- 
(1)

$$
\mathrm{H}_{2} \mathrm{C}=\mathrm{CH}-\mathrm{CH}_{2}-\mathrm{CH}_{2}-\mathrm{Cl} \underset{\mathrm{THF}}{\stackrel{\mathrm{Mg}}{\longrightarrow}} \mathrm{H}_{2} \mathrm{C}=\mathrm{CH}-\mathrm{CH}_{2}-\mathrm{CH}_{2}-\mathrm{MgCl}
$$

(2)

$$
\begin{aligned}
& \mathrm{Br}-\left(\mathrm{CH}_{2}\right)_{10}-\mathrm{COOH} \underset{-20{ }^{\circ \mathrm{C} T H F}}{\stackrel{\mathrm{CH}_{3} \mathrm{MgCl}}{\longrightarrow}} \mathrm{Br}-\left(\mathrm{CH}_{2}\right)_{10}-\mathrm{COOMgCl} \stackrel{\mathrm{H}_{2} \mathrm{C}=\mathrm{CH}-\mathrm{CH}_{2}-\mathrm{CH}_{2}-\mathrm{MgCl}}{\longrightarrow} \\
& \mathrm{H}_{2} \mathrm{C}=\mathrm{CH}-\left(\mathrm{CH}_{2}\right)_{12}-\mathrm{COOMgCl} \stackrel{\mathrm{H}_{2} \mathrm{SO}_{4(\text { aq) }}}{\longrightarrow} \mathrm{H}_{2} \mathrm{C}=\mathrm{CH}-\left(\mathrm{CH}_{2}\right)_{12}-\mathrm{COOH} \quad \text { (II) }
\end{aligned}
$$

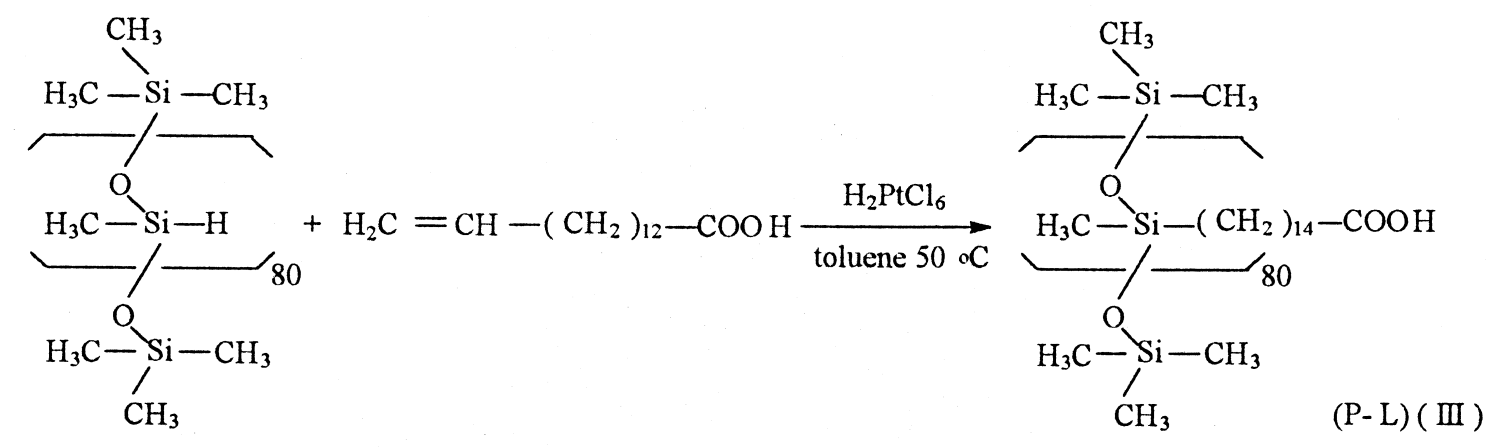

(4)
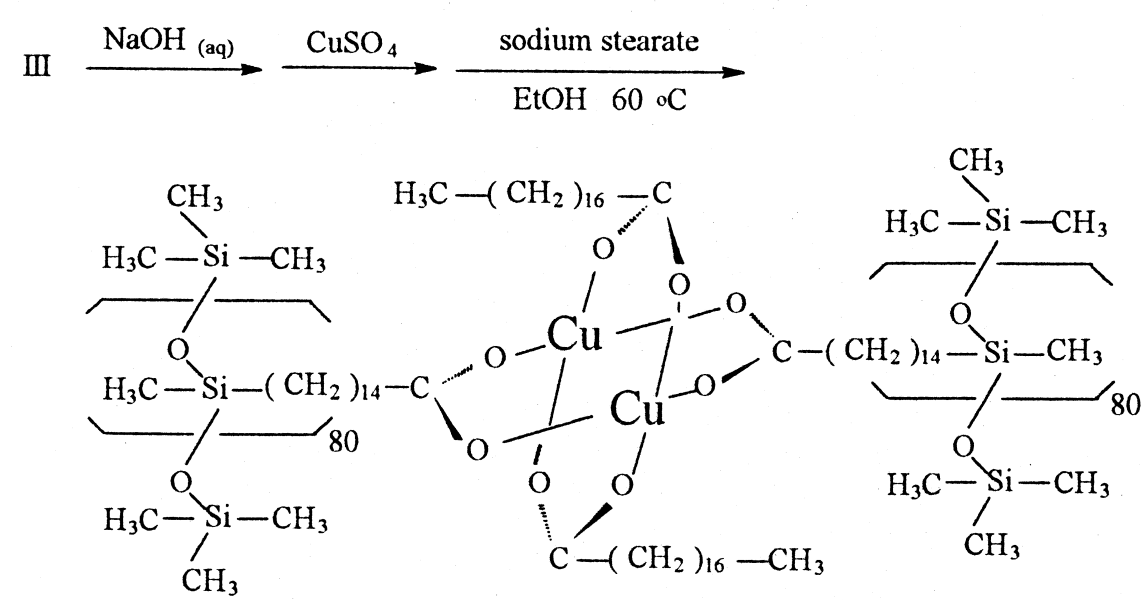

( P-LCuSt)

Fig. 1. Procedures for the preparation of the metallomesogenic polymer.

ture of $\mathrm{P}-\mathrm{LCuSt}$ in comparison with $\mathrm{CuSt}$ was observed. The enthalpy changes of the mesophasemesophase, namely $D_{L}-D_{\text {ho }}$ transition for both materials is nearly the same. A greater energy in the solid-mesophase transition was needed for the polymer might be due to the less ordered molecular 

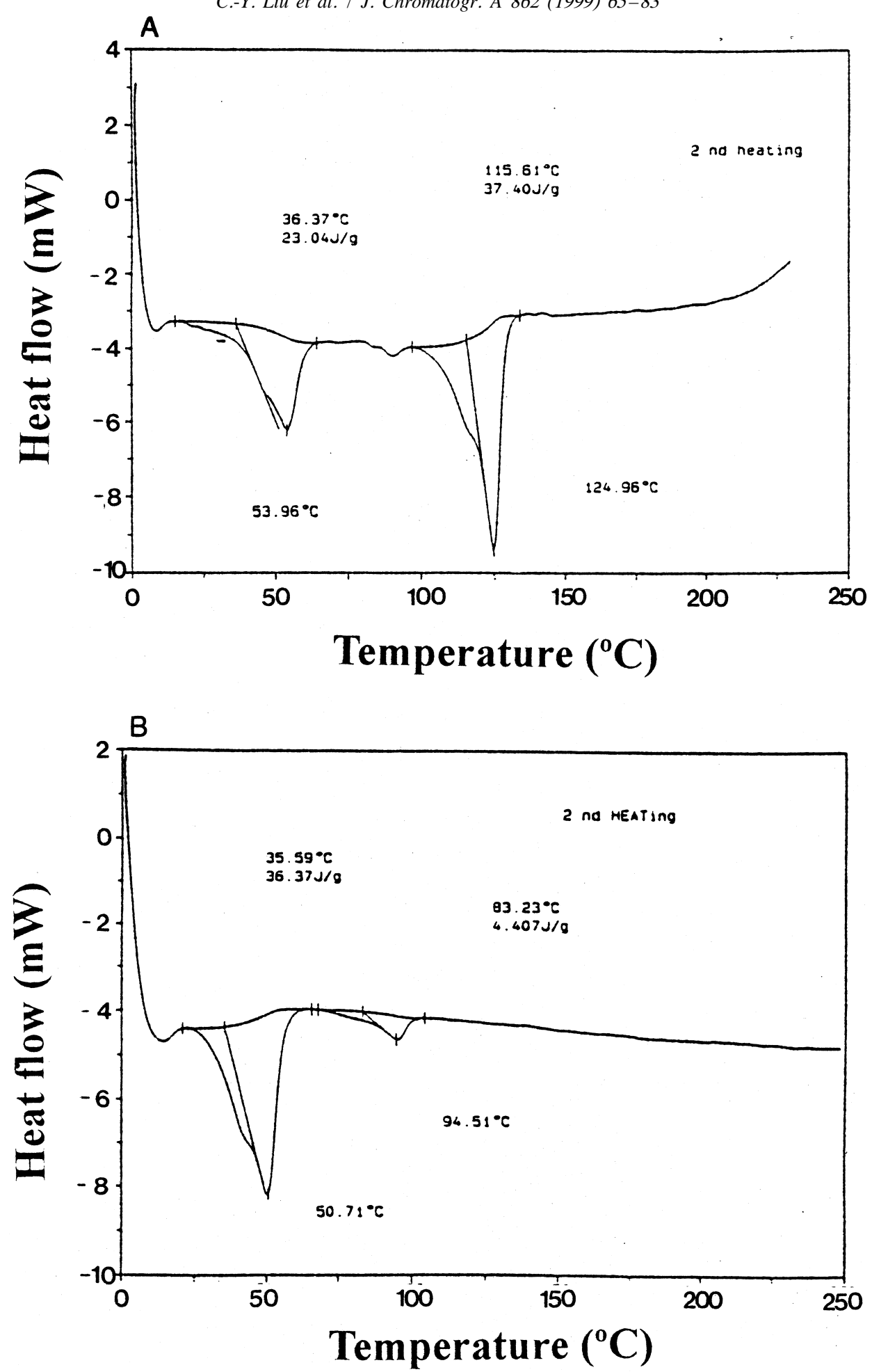

Fig. 2. Differential scanning calorimetry thermograms of metallomesogens. (A): CuSt; (B): P-LCuSt. Heating rate: $10^{\circ} \mathrm{C} \mathrm{min}{ }^{-1} ; \mathrm{N}_{2}: 100 \mathrm{ml}$ $\min ^{-1}$. 
Table 1

Phase transition temperatures and enthalpies for the mixed ligand metallomesogens ${ }^{\mathrm{a}}$

\begin{tabular}{|c|c|}
\hline Compounds & $\begin{array}{l}\text { Phase transition temperature, }{ }^{\circ} \mathrm{C} \\
\text { (corresponding enthalpy changes, } \mathrm{kJ} \mathrm{mol}^{-1} \text { ) }\end{array}$ \\
\hline $\begin{array}{l}\text { CuSt } \\
\text { P-LCuSt }\end{array}$ & $\begin{array}{l}K \text {--- } 54(14.5) \text {---- } \mathrm{D}_{\mathrm{L}} \text {---- } 125(23.6) \text {---- } \mathrm{D}_{\text {ho }} \text {---- } 200 \text {---- I } \\
K \text {---- } 50(202) \text {---- } \mathrm{D}_{\mathrm{L}} \text {---- } 95(24.5) \text {---- } \mathrm{D}_{\text {ho }} \text {---- } 200 \text {--- I }\end{array}$ \\
\hline
\end{tabular}

${ }^{a}$ Abbreviation: CuSt: Metallomesogenic monomer; P-LCuSt: Mixed ligand metallomesogenic polymer; K: Crystalline, lamellar phase; $\mathrm{D}_{\mathrm{L}}$ : Discotic lamellar phase; $\mathrm{D}_{\mathrm{ho}}$ : Ordered hexagonal columnar-discotic mesophase; I: Isotropic phase.

arrangement than that of the CuSt. Thermal gravimetric analysis (TGA) showed that there are significant weight losses around $250^{\circ} \mathrm{C}$ for both $\mathrm{CuSt}$ and $\mathrm{P}-\mathrm{LCuSt}$.

\subsection{Chromatographic evaluation}

To elucidate possible separation effects caused by the discotic metallomesogen, 16 phenols with different molecular structures were studied.

\subsubsection{Effect of ammonia on retention}

Ammonia in nitrogen has been used instead of nitrogen as carrier gas. Significant variations in retention time, detector response and peak shape were observed. The data in the parenthesis showed the retention time of each analyte when $\mathrm{P}-\mathrm{LCuSt}$ was used as the stationary phase at $75^{\circ} \mathrm{C}$. At the gas flow rate of $25 \mathrm{ml} \mathrm{min}^{-1}$ and split ratio of 50:1, the retentions for the 2-chlorophenol (2.35 $\mathrm{min}), 2$-nitrophenol (2.90 $\mathrm{min})$, phenol $(3.31 \mathrm{~min}), \quad o$ methylphenol (4.02 $\mathrm{min}), \quad p$-methylphenol (5.42 $\mathrm{min})$, 2,4,6-trichlorophenol (6.45 $\mathrm{min})$ and 2,4-dichlorophenols (7.88 $\mathrm{min}$ ) with nitrogen as carrier gas are reduced significantly to the 2-chlorophenol (1.65 $\mathrm{min}$ ), 2-nitrophenol (2.15 $\mathrm{min})$, phenol (2.55 $\mathrm{min})$, $o$-methylphenol (3.08 min), $p$-methylphenol (4.17 $\mathrm{min})$, 2,4,6-trichlorophenol (4.80 $\mathrm{min})$ and 2,4-dichlorophenols (6.12 min) when $\mathrm{N}_{2}-\mathrm{NH}_{3}(9: 1, \mathrm{v} / \mathrm{v})$ was used as carrier gas. The results indicate that a competition reaction occurred between analyte and ammonia-carrier gas toward the central metal atom of the stationary phase. In other words, a ligand exchange mechanism might exist. Moreover, pure nitrogen without the addition of ammonia as carrier gas was adopted for the further investigation owing to the high corrosion of ammonia.

\subsubsection{Effect of column temperature on retention}

To illustrate the practical utility of the prepared metallomesogens, at first we present as examples the separation of substituted phenols isocratically. Variation of inlet pressure over the range of $20-35 \mathrm{kPa}$, it was found that the optimum condition was $30 \mathrm{kPa}$, namely linear velocity of $17.7 \mathrm{~cm} \mathrm{~s}^{-1}$. Fig. 3 shows the isothermal separation of phenols at 60,70 and $80^{\circ} \mathrm{C}$, respectively. For open tubular columns, the multiple path, the $A$ term in the van Deemter equation is zero, so only longitudinal diffusion, $B$, and resistance to mass transfer, $C$, contribute to band broadening. The van Deemter plots for $o$ - and $m$ methylphenol at an oven temperature of $70^{\circ} \mathrm{C} \mathrm{dem}$ onstrated nearly identical optimum velocities. However, higher values of $B$ and $C$ for $m$-methylphenol than $o$-methylphenol was found. The result indicated that the force dispersion was more extensive through the mobile phase and diffusion was less efficient among equilibrium plates under the separation conditions for $m$-methylphenol. In other words, greater solubility for $o$-methylphenol than $m$-methylphenol in the stationary phase might be. Since the methyl group is an electron-releasing group, the property leads to a more stable complex formation toward the stationary phase for $o$-methylphenol than $m$ methylphenol. The result seems rational.

Column temperature would affect the vaporization of the analyte and the molecular arrangement of the metallomesogenic phase. Hence the retention behavior of phenols in both $\mathrm{D}_{\mathrm{L}}$ and $\mathrm{D}_{\text {ho }}$ liquid crystal phases are investigated (Fig. 4). It was found that the selectivity factor decreased on increasing column temperature for the pairs of $o-/ m$-methylphenol and 2,4,6-trichlorophenol/2,4-dinitrophenol. This might be due to the compatibility variation for the solute in each mesogenic phase at different temperature. 2Chloro-/2-nitrophenol, however, were in remarkable contrast to that, as a result of the strong tendency of 
(A)

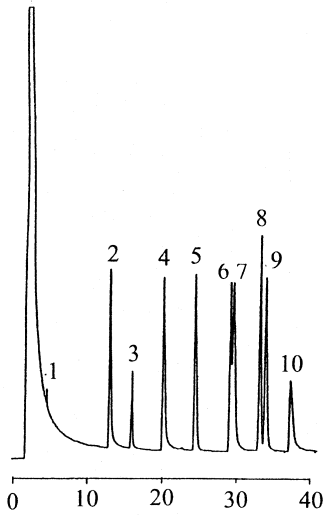

(B)

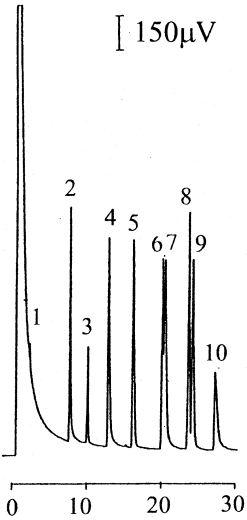

(C)

\section{Retention time (min)}

Fig. 3. Separation of phenols at various oven temperature. Stationary phase: Wall-coated capillary column (P-LCuSt, $15 \mathrm{~m} \times 0.25 \mathrm{~mm}$ I.D.). Sample concentration: $320 \mu \mathrm{g} \mathrm{ml}^{-1}$; Injection volume: $1 \mu \mathrm{l}$; Injector temperature: $290^{\circ} \mathrm{C}$; FID detector temperature: $240^{\circ} \mathrm{C}$; Inlet pressure: $30 \mathrm{kPa}$; Split ratio: 35 . Oven temperature; (A): $60^{\circ} \mathrm{C}$; (B): $70^{\circ} \mathrm{C}$; (C): $80^{\circ} \mathrm{C}$. Peak identification: (1) 3-aminophenol; (2) 2-chlorophenol; (3) 2-nitrophenol; (4) phenol; (5) o-methylphenol; (6) m-methylphenol; (7) p-methylphenol; (8) 2,4-dimethylphenol; (9) 2,4,6-trimethylphenol; (10) 2,4-dichlorophenol.

2-chlorophenol remaining in the $\mathrm{D}_{\mathrm{L}}$ state, and gave a sharp increase of capacity factor while the stationary mesophase was transformed to $\mathrm{D}_{\text {ho }}$ state.

Resolution provides a quantitative measure of its ability to separate two analytes. It is related to the separation between peaks and the average widths of the two peaks. They are correlated to the column temperature and competitive. Thus a maximum resolution would be found at a certain liquid crystal state. The results showed that the separation of 2chlorophenol/2-nitrophenol exhibited a maximum resolution in both $D_{L}$ and $D_{h o}$ state. Meanwhile, 2,4,6-trichlorophenol/2,4-dinitrophenol exhibited a maximum resolution in $\mathrm{D}_{\mathrm{ho}}$ and isotropic phases too. In contrast, the pair of $o / m$-methylphenol gave a two-step rise as the column temperature decreased. Under the circumstance of increasing column temperature, there might be a sharp increase of diffusion coefficient for mobile phase and no significant increase for stationary phase in the case of $m$ methylphenol.

By plotting plate height versus column temperature, a non-linear relationship was obtained (Fig. 5A and $\mathrm{B}$ ). For the more volatile compounds; 2-chlorophenol, 2-nitrophenol, $o$-methylphenol and $m$ - methylphenol, two curve lines indicated that there are two phases transition occurred, namely from crystalline to discotic lamellar and then to discotic hexagonal ordered phase. The temperature range between the inflection points of the curve lines might correspond to the transition temperature of the metallomesogenic polymer cross-linked to the capillary wall $\left(75-85^{\circ} \mathrm{C}\right)$. The lower transition temperature of mesomorph in the thin-film state of the capillary column than that observed in the bulk liquid (DSC) might be due to a certain amount of "locked" mobility of the polymer backbone owing to the process of cross-linking, or different heating rate compared with that in the DSC experiments. For the less volatile compounds, 2,4,6-trichlorophenol and 2,4-dinitrophenol, only one phase transition temperature, from discotic hexagonal ordered phase to isotropic phase was found.

Fig. 6A and B show the dependence of $\log k^{\prime}$ of phenols against reciprocal absolute temperature of the polymeric metallomesogen, P-LCuSt. By considering the solute-solvent diffusivity, there are two metallomesogenic phases, $D_{L}$ and $D_{h o}$ exist in Fig. 6A, while only one phase, $\mathrm{D}_{\mathrm{ho}}$ exist in Fig. 6B. Since the compatibility of all substituted phenols 


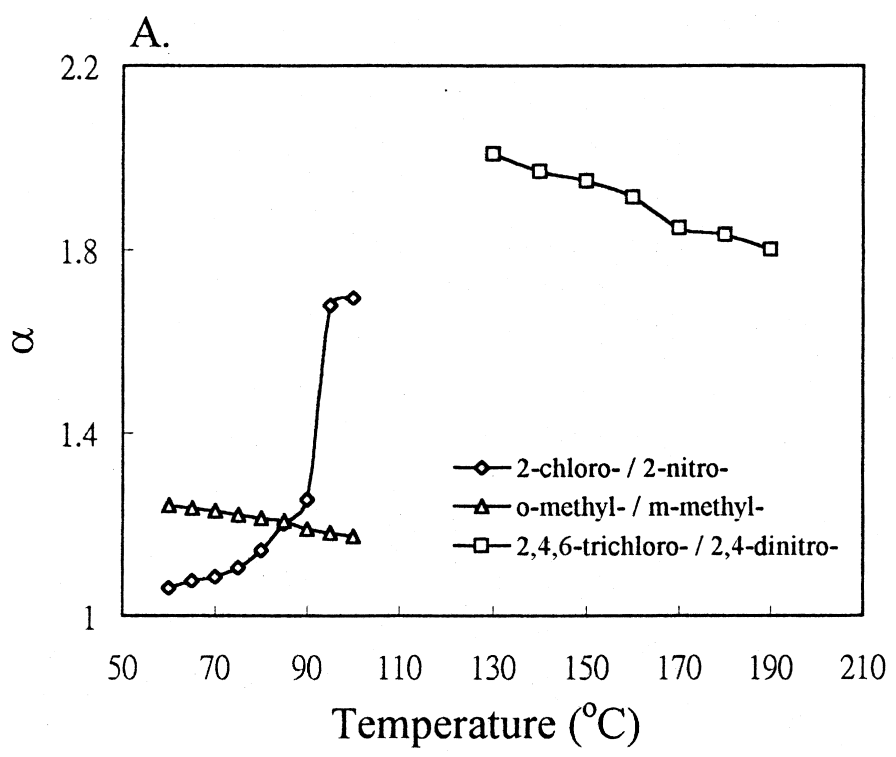

B.

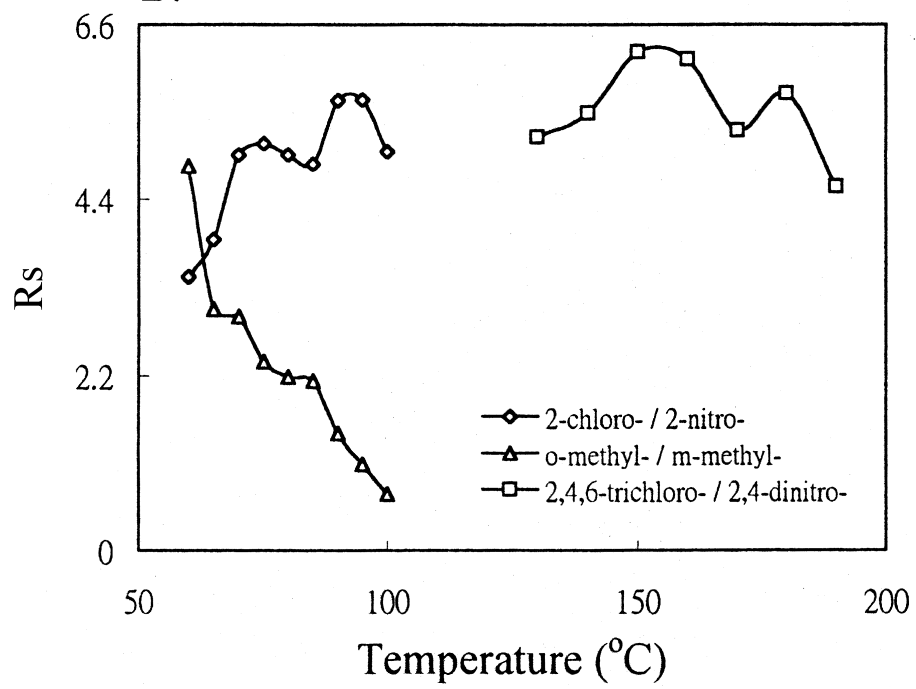

Fig. 4. Separation efficiency as a function of column temperature for the phenols. Conditions as in Fig. 3; (A): Plots of selectivity factor ( $\alpha$ ) against column temperature; $(\mathrm{B})$ : Plots of resolution $\left(R_{s}\right)$ against column temperature.

with the metallomesogenic polymer can not be the same, a greater variation of the solute solubility between $D_{L}$ and $D_{\text {ho }}$ phases (Fig. 6A) exhibit a more distinct phase transition. Only one liquid crystalline phase $\left(D_{h o}\right)$ existed over the temperature range studied (Fig. 6B), so linear line was indicated.
In this work, boiling temperatures of the compounds lie in a wide range from 164 to $310^{\circ} \mathrm{C}$. It is not easy to separate all of them isothermally within a reasonable time. The mixture of 3-aminophenol, 2chlorophenol, 2-nitrophenol, phenol, omethylphenol, $m$-methylphenol, $p$-methylphenol, 


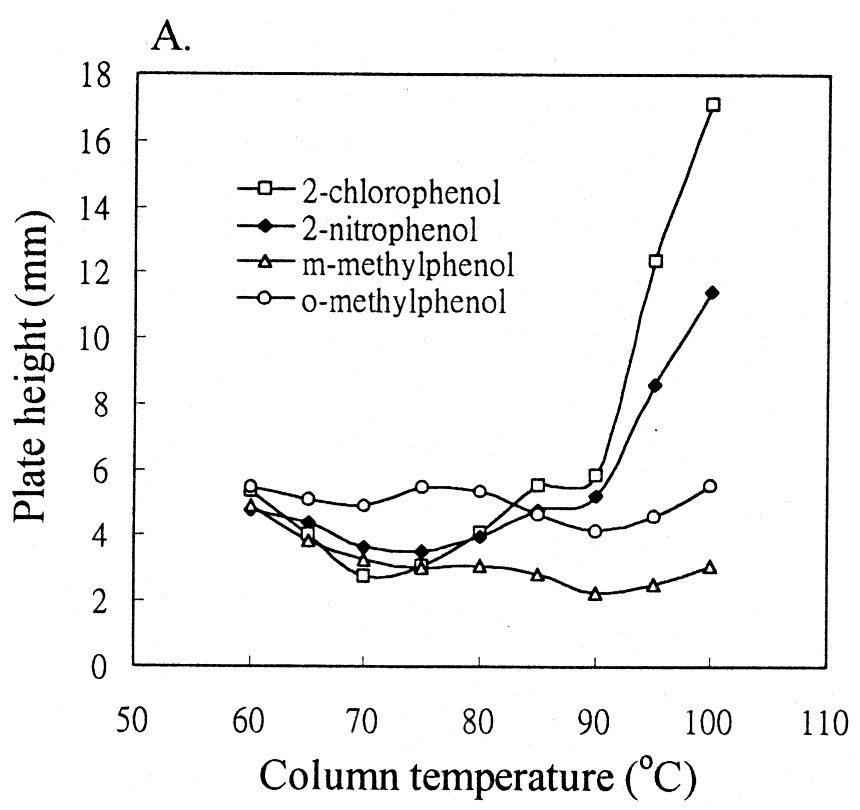

B.

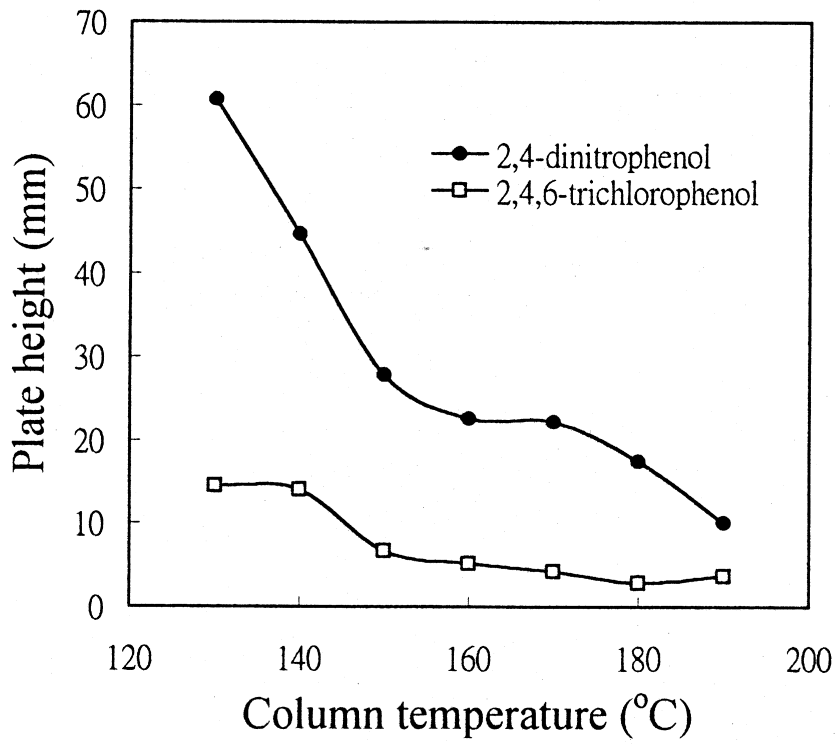

Fig. 5. The plate height as a function of column temperature. Conditions as in Fig. 3.

2,4-dimethylphenol, 2,4,6-trimethylphenol and 2,4dichlorophenol could be separated within $38 \mathrm{~min}$ at $60^{\circ} \mathrm{C}, 28 \mathrm{~min}$ at $70^{\circ} \mathrm{C}$ and $21 \mathrm{~min}$ at $80^{\circ} \mathrm{C}$, respectively (Fig. 3). However, 4-bromophenol, 3-methyl4-chlorophenol, 2,4,6-trichlorophenol, 2,4-dinitro- phenol, 4-nitrophenol and pentachlorophenol could not be eluted under the mentioned conditions. Fig. 7 provides the programmed temperature separation of a synthetic mixture of 16 phenols encountered most frequently in environmental samples. By changing 


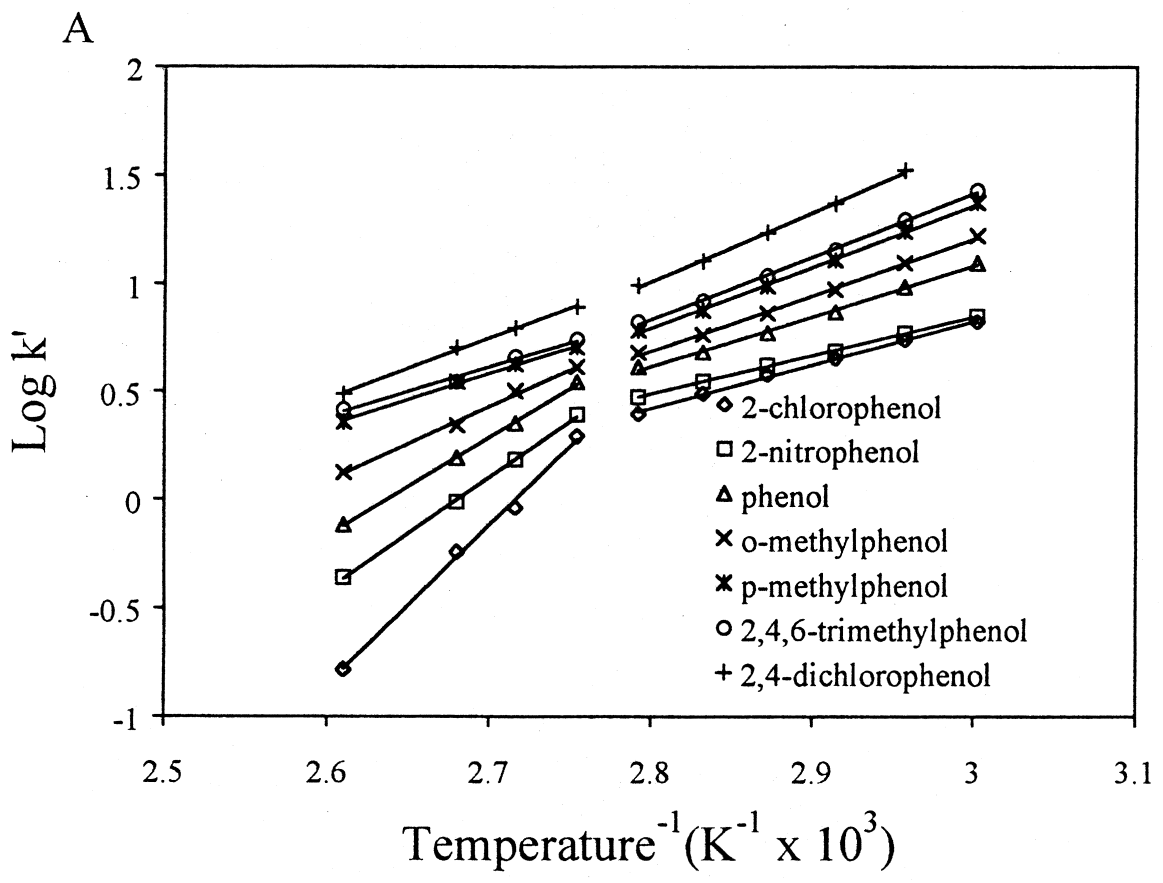

B

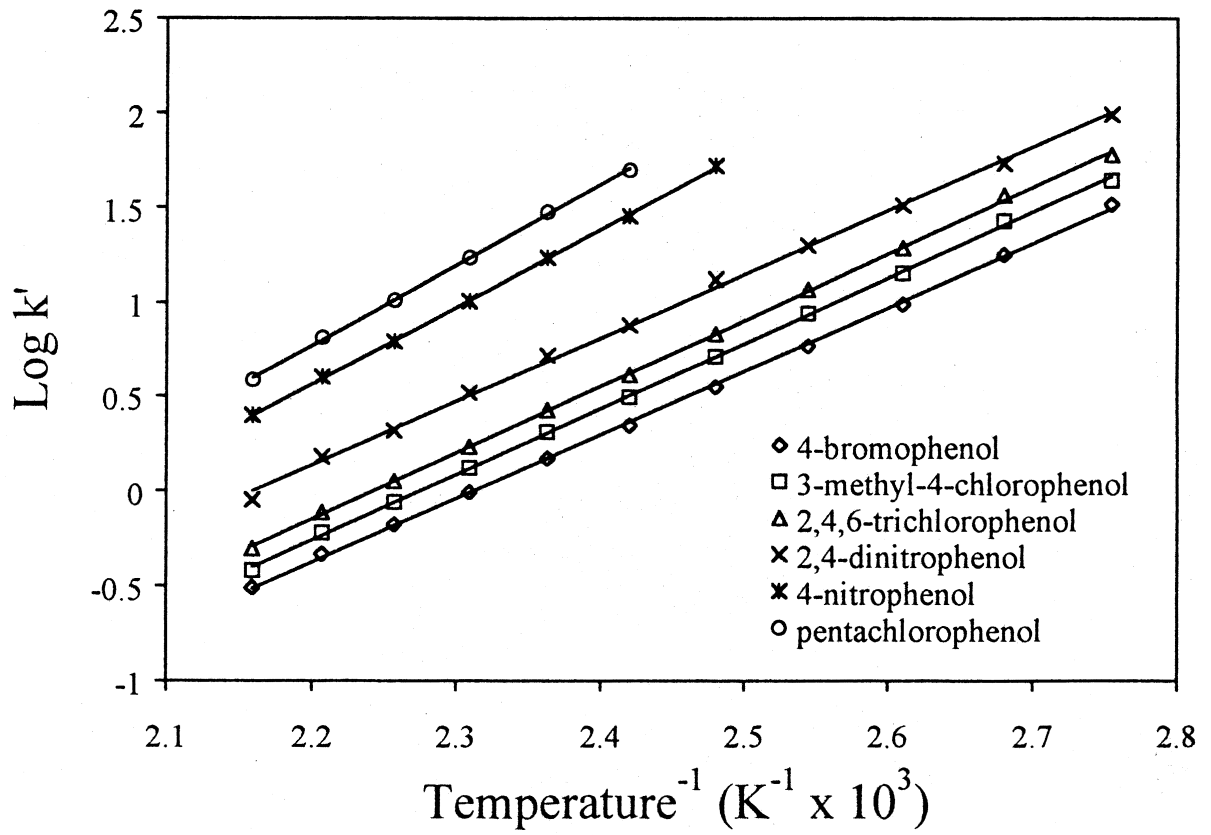

Fig. 6. Van't Hoff plots of phenols. Stationary phase: Wall-coated capillary column (P-LCuSt, $15 \mathrm{~m} \times 0.25 \mathrm{~mm}$ I.D.). Sample concentration: $320 \mu \mathrm{g} \mathrm{ml}^{-1}$; Injection volume: $1 \mu \mathrm{l}$; Injector temperature: $290^{\circ} \mathrm{C}$; FID detector temperature: $240^{\circ} \mathrm{C}$; Inlet pressure: $30 \mathrm{kPa}$; Split ratio: 35 . 

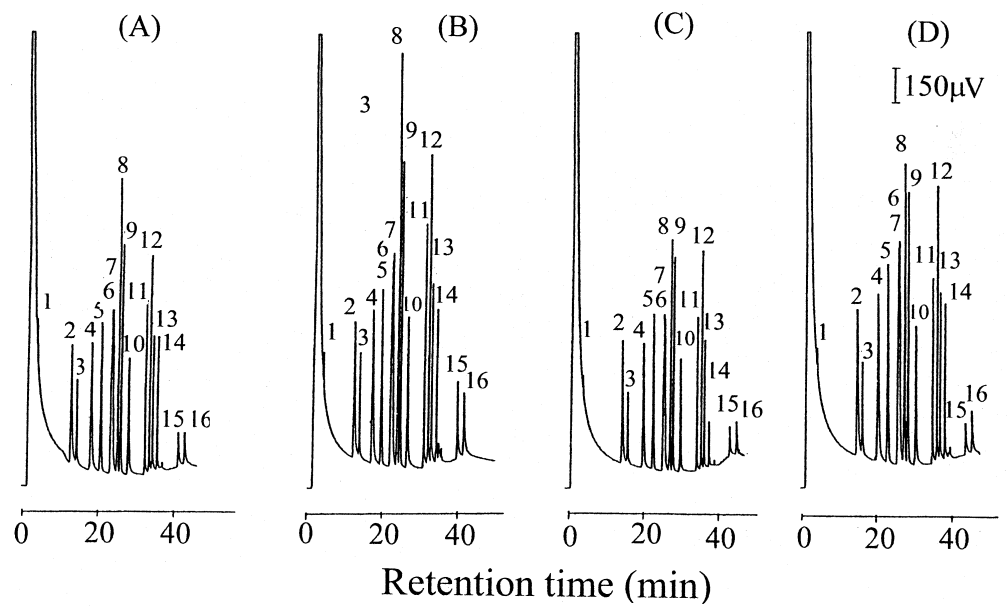

Fig. 7. Programmed-temperature separation of 16 phenols. Conditions as in Fig. 3, except column temperatures are; (A): $50^{\circ} \mathrm{C}(5 \mathrm{~min})$ to $85^{\circ} \mathrm{C}(1 \mathrm{~min})$ at $3^{\circ} \mathrm{C} \mathrm{min}^{-1}$, then to $180^{\circ} \mathrm{C}$ at $7^{\circ} \mathrm{C} \min ^{-1}$; $(\mathrm{B}): 45^{\circ} \mathrm{C}(5 \mathrm{~min})$ to $85^{\circ} \mathrm{C}(1 \mathrm{~min})$ at $1^{\circ} \mathrm{C} \min ^{-1}$, then to $180^{\circ} \mathrm{C}$ at $7^{\circ} \mathrm{C} \min { }^{-1} ;(\mathrm{C})$ : $45^{\circ} \mathrm{C}(5 \mathrm{~min})$ to $85^{\circ} \mathrm{C}(5 \mathrm{~min})$ at $2^{\circ} \mathrm{C} \min ^{-1}$, then to $180^{\circ} \mathrm{C}$ at $7^{\circ} \mathrm{C} \min ^{-1}$; (D): $45^{\circ} \mathrm{C}(5 \mathrm{~min})$ to $85^{\circ} \mathrm{C}(1 \mathrm{~min})$ at $2^{\circ} \mathrm{C}$ min ${ }^{-1}$, then to $180^{\circ} \mathrm{C}$ at $7^{\circ} \mathrm{C} \mathrm{min}^{-1}$. Peak identification: (1) 3-aminophenol; (2) 2-chlorophenol; (3) 2-nitrophenol; (4) phenol; (5) o-methylphenol; (6) $\mathrm{m}$ methylphenol; (7) p-methylphenol; (8) 2,4-dimethylphenol; (9) 2,4,6-trimethylphenol; (10) 2,4-dichlorophenol; (11) 4-bromophenol; (12) 3-methyl-4-chlorophenol; (13) 2,4,6-trichlorophenol; (14) 2,4-dinitrophenol; (15) 4-nitrophenol; (16) pentachlorophenol.

the oven temperature rising rate and holding time at an initial temperature of $45^{\circ} \mathrm{C}$ and final temperature of $180^{\circ} \mathrm{C}$, satisfactory separations were obtained.

\subsection{Thermodynamic behavior}

Gas chromatography is often the method of choice for the determination of reliable thermodynamic data for volatile solutes, under conditions of approximately infinite dilution. The thermodynamic properties obtained can provide information on the factors that are important in solute-liquid crystal interactions and how they vary as a function of mesophase structure. This information is ultimately useful for further development of models of retention and selectivity that will permit the logical design and application of a particular liquid crystal stationary phase for a desired separation.

The infinite-dilution solute partial molar enthalpy and entropy of solution can be obtained by means of the following equations [16-18].

$$
\begin{aligned}
& \ln V_{g}^{o}=\frac{-\Delta H}{R T}+\frac{\Delta S}{R}-\ln \left(\frac{M}{273.3 R}\right), \\
& V_{g}^{o}=V^{\prime} / W,
\end{aligned}
$$

$V^{\prime}=\left(t_{r}-t_{o}\right) \times f$

where $t_{r}$ is the retention time of the sample; $t_{o}$ is the retention time of the non-adsorbed substance; $V^{\prime}$ is the retention volume; $f$ is the flow rate of the carrier gas; $W$ is the weight of the stationary phase; $M$ is the molecular weight of the stationary phase; and $V_{g}^{o}$ is the specific retention volume.

Combining the equations shown above, by plotting $\ln \left(t_{r}-t_{o}\right)$ versus $1 / T$ as shown in Fig. 8A and B can yield $\Delta H$ (from the slope). The results are summarized in Tables 2 and 3 . To address directly the separation mechanism of the solutes in a given metallomesogen, differences in the respective thermodynamic parameters need to be considered. Table 4 indicates the enthalpy and entropy differences of solutes between the hexagonal ordered $\left(\mathrm{D}_{\mathrm{ho}}\right)$ and lamellar $\left(\mathrm{D}_{\mathrm{L}}\right)$ phases. $\Delta H_{(\mathrm{L}-\mathrm{ho})}$ assigned as $\Delta H_{(\mathrm{g}-\mathrm{ho})}-\Delta H_{(\mathrm{g}-\mathrm{L})}$ was in the decreasing order of 2,4,6-trimethylphenol $>p$-methylphenol $>2,4$ dichlorophenol $>o$-methylphenol $>$ phenol $>2$-nitrophenol $>2$-chlorophenol which is similar as that of $\Delta H_{(\mathrm{g}-\mathrm{ho})} . \Delta S_{(\mathrm{L}-\mathrm{ho})}$ assigned as $\Delta S_{(\mathrm{g}-\mathrm{ho})}-\Delta S_{(\mathrm{g}-\mathrm{L})}$ was of a similar order. The greater $\Delta H_{(\mathrm{L}-\mathrm{ho})}$ would experience stronger solute-lamellar $\left(\mathrm{D}_{\mathrm{L}}\right)$ phase interaction. In a similar manner, the greater $\Delta S_{(\mathrm{L}-\mathrm{ho})}$ 

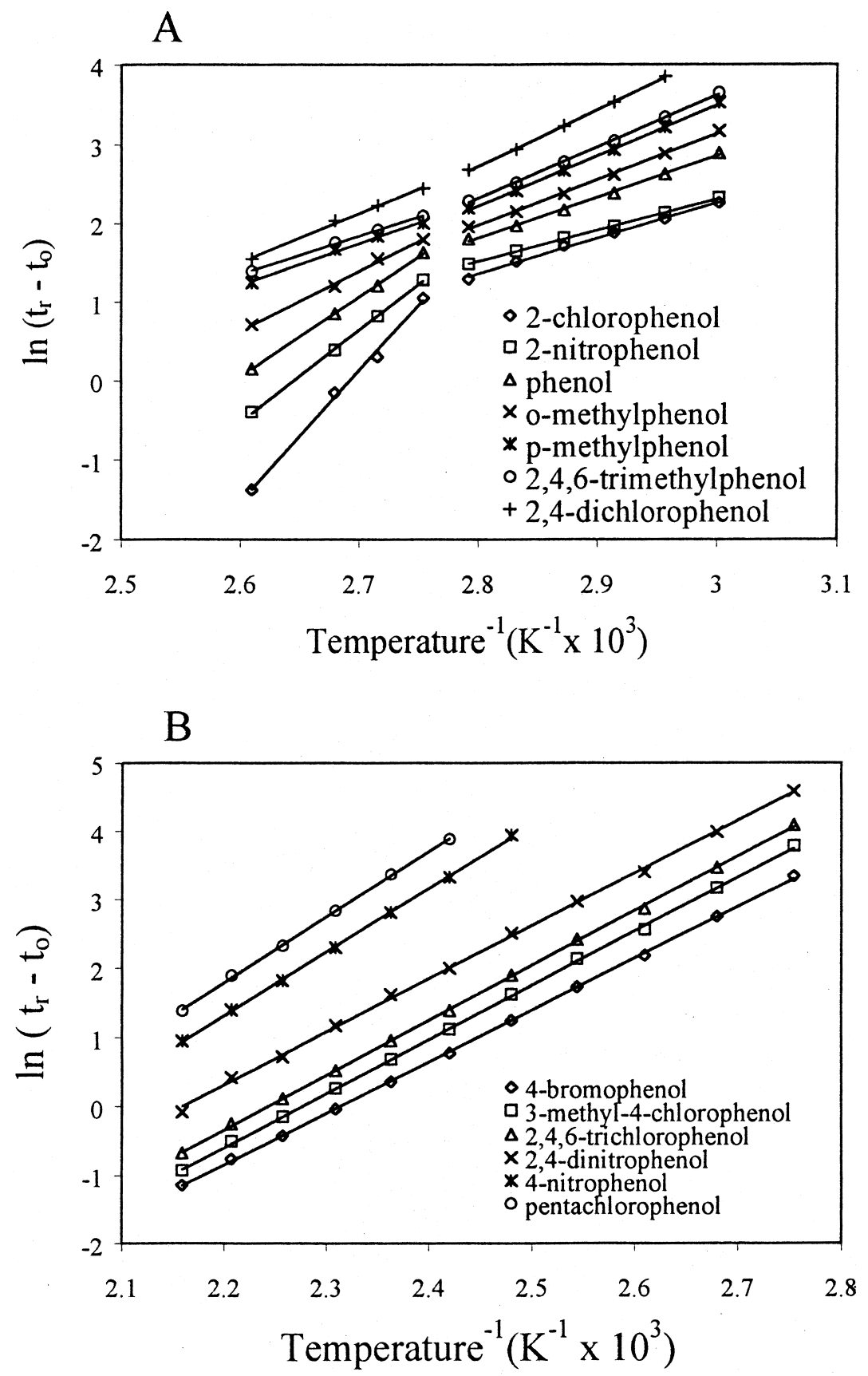

Fig. 8. Experimental dependences $\ln \left(t_{r}-t_{o}\right)$ versus reciprocal absolute temperature for substituted phenols on a novel wall-coated capillary column.

indicates that the solutes are more compatible with the ordered lamellar $\left(D_{L}\right)$ phase than with the $D_{\text {ho }}$ phase. A molecule with greater symmetry and more basicity would be more accordant with the mentioned property. Further we calculate the Gibbs free energy at the coexistent temperature of $\mathrm{D}_{\mathrm{L}}$ and $\mathrm{D}_{\text {ho }}$ 
Table 2

The enthalpy changes of solutes from the ideal gaseous state to actual solution obtained from the plotting $\ln \left(t_{r}-t_{o}\right)$ versus reciprocal temperature $^{\text {a }}$

\begin{tabular}{llllll}
\hline Compound & $\begin{array}{l}\mathrm{D}_{\mathrm{L}} \text { mesophase } \\
\left(60-85^{\circ} \mathrm{C}\right)\end{array}$ & & $\begin{array}{l}\mathrm{D}_{\mathrm{ho}} \text { mesophase } \\
\left(90-110^{\circ} \mathrm{C}\right)\end{array}$ \\
\cline { 2 - 3 } \cline { 5 - 6 } & $y: \ln \left(t_{r}-t_{o}\right) ; x: 1 / T \times 10^{3}$ & $-\Delta H_{(\mathrm{g}-\mathrm{L})}\left(\mathrm{kJ} \mathrm{mol}^{-1}\right)$ & & $y: \ln \left(t_{r}-t_{o}\right) ; x: 1 / T \times 10^{3}$ & $-\Delta H_{(\mathrm{g}-\mathrm{ho})}\left(\mathrm{kJ} \mathrm{mol}^{-1}\right)$ \\
\hline 2-Chlorophenol & $y=4.54 x-11.36(r=0.9985)$ & 37.78 & $y=16.60 x-44.69(r=0.9980)$ & 138.16 \\
2-Nitrophenol & $y=3.98 x-9.64(r=0.9996)$ & 33.14 & $y=11.69 x-30.92(r=0.9997)$ & 97.28 \\
Phenol & $y=5.23 x-12.82(r=0.9984)$ & 42.84 & $y=10.20 x-26.48(r=0.9997)$ & 84.89 \\
--Methylphenol & $y=5.82 x-14.32(r=0.9989)$ & 48.41 & $y=7.62 x-19.18(r=0.9979)$ & 63.39 \\
$p$-Methylphenol & $y=6.35 x-15.56(r=0.9994)$ & 52.84 & $y=5.30 x-12.57(r=0.9971)$ & 44.10 \\
2,4,6-Trimethylphenol & $y=6.49 x-15.85(r=0.9994)$ & 54.02 & $y=4.91 x-11.41(r=0.9993)$ & 40.84 \\
2,4-Dichlorophenol & $y=7.12 x-17.21(r=0.9997)$ & 59.25 & $y=6.24 x-14.73(r=0.9979)$ & 51.97 \\
\hline
\end{tabular}

${ }^{a}$ Abbreviation: $\mathrm{D}_{\mathrm{L}}$ : discotic lamellar phase; $\mathrm{D}_{\mathrm{ho}}$ : hexagonal ordered phase; $\Delta H_{(\mathrm{g}-\mathrm{L})}$ : enthalpy change from the ideal gaseous solution to $\mathrm{D}_{\mathrm{L}}$ stationary phase; $\Delta H_{(\mathrm{g}-\mathrm{ho})}$ : enthalpy change from the ideal gaseous solution to $\mathrm{D}_{\mathrm{ho}}$ stationary phase.

Table 3

The enthalpy changes of solutes from the ideal gaseous state to actual solution obtained from the plotting $\ln \left(t_{r}-t_{o}\right)$ versus reciprocal temperature $^{\mathrm{a}}$

\begin{tabular}{lll}
\hline Compound & \multicolumn{1}{c}{$\mathrm{D}_{\mathrm{ho}}$ mesophase $\left(90-190^{\circ} \mathrm{C}\right)$} & $-\Delta H_{(\mathrm{g}-\mathrm{ho})}\left(\mathrm{kJ} \mathrm{mol}^{-1}\right)$ \\
\cline { 2 - 3 } & $y: \ln \left(t_{r}-t_{o}\right) ; x: 1 / T \times 10^{3}$ & 62.22 \\
4-Bromophenol & $y=7.48 x-17.29(r=0.9998)$ & 65.19 \\
3-Methyl-4-chlorophenol & $y=7.84 x-17.83(r=0.9998)$ & 66.07 \\
2,4,6-Trichlorolphenol & $y=7.94 x-17.80(r=0.9998)$ & 63.97 \\
2,4-Dinitrophenol & $y=7.69 x-16.60(r=0.9995)$ & 77.03 \\
4-Nitrophenol & $y=9.25 x-19.05(r=0.9997)$ & 79.66 \\
Pentachlorophenol & $y=9.57 x-19.26(r=0.9998)$ & \\
\hline
\end{tabular}

${ }^{\mathrm{a}}$ Abbreviation: $\mathrm{D}_{\mathrm{ho}}$ : hexagonal ordered phase; $\Delta H_{(\mathrm{g}-\mathrm{ho})}$ : enthalpy change from the ideal gaseous solution to $\mathrm{D}_{\mathrm{ho}}$ stationary phase.

phase $\left(87.5^{\circ} \mathrm{C}\right)$. All are approaching zero, except unsubstituted phenol (Table 4). The results provide a reasonable explanation where phenol is more compatible with the $\mathrm{D}_{\text {ho }}$ than all other substituted phenols.
The mechanisms of retention could be also studied via the temperature dependence of the relative retention, $\alpha$ of isomeric solute pairs [16]. The relevant equation for the solute pair is as the following equation.

Table 4

Enthalpy and entropy changes from mesophase to isotropic phase for the substituted phenols ${ }^{\mathrm{a}}$

\begin{tabular}{lccc}
\hline Compound & $\Delta H_{(\mathrm{L}-\mathrm{ho})}\left(\mathrm{kJ} \mathrm{mol}^{-1}\right)$ & $\Delta S_{(\mathrm{L}-\mathrm{ho})}\left(\mathrm{J} \mathrm{mol}^{-1} \mathrm{~K}^{-1}\right)$ & $\left.\Delta G_{(\mathrm{L}-\mathrm{ho})}(\mathrm{kJ} \mathrm{mol})^{-1}\right)$ \\
\hline 2-Chlorophenol & -100.33 & -277.40 & -0.29 \\
2-Nitrophenol & -64.10 & -177.11 & -0.25 \\
Phenol & -42.09 & -113.72 & -1.05 \\
$o$-Methylphenol & -14.98 & -40.50 & -0.38 \\
$p$-Methylphenol & 8.74 & 24.94 & -0.25 \\
2,4,6-Trimethylphenol & 13.18 & 36.90 & -0.13 \\
2,4-Dichlorophenol & 7.28 & 20.63 & -0.17
\end{tabular}

${ }^{\mathrm{a}} \Delta H_{(\mathrm{L}-\mathrm{ho})}=\Delta H_{(\mathrm{g}-\mathrm{ho})}-\Delta H_{(\mathrm{g}-\mathrm{L})}$, enthalpy change from $\mathrm{D}_{\mathrm{L}}$ to $\mathrm{D}_{\mathrm{ho}}$ mesophase; $\Delta S_{(\mathrm{L}-\mathrm{ho})}=\Delta S_{(\mathrm{g}-\mathrm{ho})}-\Delta S_{(\mathrm{g}-\mathrm{L})}$, entropy change from $\mathrm{D}_{\mathrm{L}}$ to $\mathrm{D}_{\mathrm{ho}}$ mesophase; $\Delta G_{(\mathrm{L}-\mathrm{ho})}=\Delta H_{(\mathrm{L}-\mathrm{ho})}-T \Delta S_{(\mathrm{L}-\mathrm{ho})}\left(T=87.5^{\circ} \mathrm{C}\right)$; Gibbs free energy change from $\mathrm{D}_{\mathrm{L}}$ to $\mathrm{D}_{\mathrm{ho}}$ mesophase. 
$\ln \alpha_{(\mathrm{B} / \mathrm{A})}=\frac{\Delta\left(\Delta H^{o}\right)_{\mathrm{B}-\mathrm{A}}}{R T}-\frac{\Delta\left(\Delta S^{o}\right)_{\mathrm{B}-\mathrm{A}}}{R}$

Where $\Delta(\Delta)_{\mathrm{B}-\mathrm{A}}$ indicates the value for $\mathrm{B}$ minus that for A. $\Delta\left(\Delta H^{o}\right)_{\mathrm{B}-\mathrm{A}}$ and $\Delta\left(\Delta S^{o}\right)_{\mathrm{B}-\mathrm{A}}$ values may be obtained from the slopes and intercepts of plots of $\ln$ $\alpha_{\text {(B/A) }}$ versus $T^{-1}$. Comparing the enthalpy, entropy and Gibbs free energy differences between pairs of substituted phenols in $D_{L}$ and $D_{h o}$ mesophases, unfortunately not all results (Tables 5 and 6) calculated from plotting of $\ln \alpha$ versus $T^{-1}$ (Fig. 9A and B) correspond to those calculated by plotting $\ln$ $\left(t_{r}-t_{o}\right)$ versus $T^{-1}$ (Fig. 8A and B). Moreover, the negative value of Gibbs free energy reveal that the phenol substituents are compatible with the prepared metallomesogen.

\subsection{Mechanism for the separation}

The factors responsible for the elution order of phenolic homologues were considered to be as follows.

\subsubsection{Vapor pressure of samples}

Like most common GLC systems, the volatility of solutes contributed great thermostatic effects to the gaseous population of various molecules and, via the procedure of vaporization at the injector, kinetic concerns about concomitant partition actions in column. Chromatograms in Fig. 7 show most of the separations follow the boiling point of phenols. However, some exceptions were found as 2-nitrophenol $\left(214^{\circ} \mathrm{C}\right)$ was eluted ahead phenol $\left(180^{\circ} \mathrm{C}\right)$, $o$-methylphenol $\left(191^{\circ} \mathrm{C}\right), p$-methylphenol $\left(202^{\circ} \mathrm{C}\right)$, $m$-methylphenol $\quad\left(203^{\circ} \mathrm{C}\right), \quad 2,4$-dichlorophenol $\left(210^{\circ} \mathrm{C}\right)$ and 2,4 -dimethyl phenol $\left(211^{\circ} \mathrm{C}\right) ; \mathrm{m}$ methylphenol $\left(203^{\circ} \mathrm{C}\right)$ eluted ahead $p$-methylphenol $\left(202^{\circ} \mathrm{C}\right)$; as well as 2,4-dichlorophenol $\left(210^{\circ} \mathrm{C}\right)$ eluted after 2,4-dimethylphenol $\left(211^{\circ} \mathrm{C}\right)$ and $2,4,6$ trimethylphenol $\left(220^{\circ} \mathrm{C}\right)$. Additionally, 4-bromophenol and 3-methyl-4-chlorophenol with the same boiling point, are well baseline separated.

\subsubsection{Polarity interaction}

Phenols are moderately polar compounds with an aromatic ring, thus trifluoropropylmethyl polysiloxane or blended diphenyl- and dimethyl polysiloxane were conventionally used as separation column. Through a narrow scrutiny of the retention order of these compounds, as 2-chlorophenol, phenol, 2-nitro-

Table 5

Enthalpy, entropy and Gibbs free energy differences between a pair of substituted phenols in $D_{L}$ and $D_{\text {ho }}$ mesophases

\begin{tabular}{|c|c|c|c|c|c|c|c|c|c|c|c|c|}
\hline \multirow{3}{*}{$\begin{array}{l}\text { Substituted phenols } \\
\text { pairs (A-B) }\end{array}$} & \multicolumn{6}{|c|}{$\mathrm{D}_{\mathrm{L}}$ mesophase $\left(60-85^{\circ} \mathrm{C}\right)$} & \multicolumn{6}{|c|}{$\mathrm{D}_{\text {ho }}$ mesophase $\left(90-110^{\circ} \mathrm{C}\right)$} \\
\hline & \multicolumn{2}{|c|}{$\begin{array}{l}\Delta \Delta H_{(\mathrm{B}-\mathrm{A})}{ }^{\mathrm{a}} \\
\left(\mathrm{kJ} \mathrm{mol}^{-1}\right)\end{array}$} & \multicolumn{2}{|c|}{$\begin{array}{l}\Delta \Delta S_{(\mathrm{B}-\mathrm{A})}^{\mathrm{b}} \\
\left(\mathrm{J} \mathrm{mol}^{-1} \mathrm{~K}^{-1}\right)\end{array}$} & \multicolumn{2}{|c|}{$\begin{array}{l}\Delta \Delta G_{(\mathrm{B}-\mathrm{A})}{ }^{\mathrm{c}} \\
\left(\mathrm{kJ} \mathrm{mol}^{-1}\right)\end{array}$} & \multicolumn{2}{|c|}{$\begin{array}{l}\Delta \Delta H_{(\mathrm{B}-\mathrm{A})}{ }^{\mathrm{a}} \\
\left(\mathrm{kJ} \mathrm{mol}^{-1}\right)\end{array}$} & \multicolumn{2}{|c|}{$\begin{array}{l}\Delta \Delta S_{(\mathrm{B}-\mathrm{A})}^{\mathrm{b}} \\
\left(\mathrm{J} \mathrm{mol}^{-1} \mathrm{~K}^{-1}\right)\end{array}$} & \multicolumn{2}{|c|}{$\begin{array}{l}\Delta \Delta G_{(\mathrm{B}-\mathrm{A})}{ }^{\mathrm{c}} \\
\left(\mathrm{kJ} \mathrm{mol}{ }^{-1}\right)\end{array}$} \\
\hline & I & II & I & II & I & II & I & II & I & II & I & II \\
\hline $\begin{array}{l}\text { 2-Chlorophenol - } \\
\text { 2-Nitrophenol }\end{array}$ & 4.64 & 4.64 & 14.31 & 14.27 & -0.29 & -0.29 & 40.88 & 41.67 & 114.60 & 116.94 & -1.88 & -1.97 \\
\hline $\begin{array}{l}\text { 2-Nitrophenol - } \\
\text { Phenol }\end{array}$ & -9.67 & -13.10 & -26.48 & -34.60 & -0.54 & -1.13 & 12.38 & 11.88 & 36.94 & 35.65 & -1.42 & -1.42 \\
\hline $\begin{array}{l}\text { Phenol - } \\
o \text {-Methylphenol }\end{array}$ & -5.61 & -4.94 & -12.47 & -12.47 & -1.30 & -0.63 & 21.51 & 22.59 & 60.75 & 63.55 & -1.17 & -1.13 \\
\hline $\begin{array}{l}o \text {-Methylphenol - } \\
p \text {-Methylphenol }\end{array}$ & -4.44 & -4.44 & -10.38 & -10.33 & -0.84 & -0.84 & 19.29 & 18.49 & 55.06 & 52.80 & -1.25 & -1.21 \\
\hline $\begin{array}{l}p \text {-Methylphenol - } \\
\text { 2,4,6-Trimethylphenol }\end{array}$ & -1.13 & -1.09 & -2.38 & -2.26 & -0.33 & -0.33 & 3.26 & 3.31 & 9.62 & 9.67 & -0.33 & -0.33 \\
\hline $\begin{array}{l}\text { 2,4,6-Trimethylphenol - } \\
\text { 2,4-Dichlorophenol }\end{array}$ & -5.23 & -6.44 & -11.38 & -14.77 & -1.34 & -1.34 & -11.13 & -11.21 & -27.66 & -27.87 & -0.84 & -0.84 \\
\hline
\end{tabular}

${ }^{\mathrm{a}} \Delta \Delta H_{(\mathrm{B}-\mathrm{A})}=\Delta H_{\mathrm{B}}-\Delta H_{\mathrm{A}}$.

${ }^{\mathrm{b}} \Delta \Delta S_{(\mathrm{B}-\mathrm{A})}=\Delta S_{\mathrm{B}}-\Delta S_{\mathrm{A}}$.

${ }^{\mathrm{c}} \Delta \Delta G_{(\mathrm{B}-\mathrm{A})}=\Delta \Delta H_{(\mathrm{B}-\mathrm{A})}-T \Delta \Delta S_{(\mathrm{B}-\mathrm{A})}$ ( $T$ is the average temperature of working range); (I) data from the plotting $\ln t_{r}-t_{o}$ versus $T^{-1}$; (II) data from the plotting $\ln \alpha$ versus $T^{-1}$. 
Table 6

Enthalpy, entropy and Gibbs free energy differences between a pair of substituted phenols in $\mathrm{D}_{\text {ho }}$ mesophase

\begin{tabular}{|c|c|c|c|c|c|c|}
\hline \multirow{3}{*}{$\begin{array}{l}\text { Substituted phenols } \\
\text { pairs }(A-B)\end{array}$} & \multicolumn{6}{|c|}{$\mathrm{D}_{\text {ho }}$ mesophase $\left(90-190^{\circ} \mathrm{C}\right)$} \\
\hline & \multicolumn{2}{|c|}{$\begin{array}{l}\Delta \Delta H_{(\mathrm{B}-\mathrm{A})}^{\mathrm{a}} \\
\left(\mathrm{kJ} \mathrm{mol}^{-1}\right)\end{array}$} & \multicolumn{2}{|c|}{$\begin{array}{l}\Delta \Delta S_{(\mathrm{B}-\mathrm{A})}^{\mathrm{b}} \\
\left(\mathrm{J} \mathrm{mol}^{-1} \mathrm{~K}^{-1}\right)\end{array}$} & \multicolumn{2}{|c|}{$\begin{array}{l}\Delta \Delta G_{(\mathrm{B}-\mathrm{A})}{ }^{\mathrm{c}} \\
\left(\mathrm{kJ} \mathrm{mol}^{-1}\right)\end{array}$} \\
\hline & I & II & I & II & I & II \\
\hline $\begin{array}{l}\text { 4-Bromophenol - } \\
\text { 3-Methyl-4-chlorophenol }\end{array}$ & 40.88 & 41.67 & 114.60 & 116.94 & -1.13 & -4.81 \\
\hline $\begin{array}{l}\text { 3-Methyl-4-chlorophenol - } \\
\text { 2,4,6-Trichlorophenol }\end{array}$ & 12.38 & 11.88 & 36.94 & 35.65 & -0.92 & -4.52 \\
\hline $\begin{array}{l}\text { 2,4,6-Trichlorophenol - } \\
\text { 2,4-Dinitrophenol }\end{array}$ & 21.51 & 22.59 & 60.75 & 63.55 & -2.05 & -6.78 \\
\hline $\begin{array}{l}\text { 2,4-Dinitrophenol - } \\
\text { 4-Nitrophenol }\end{array}$ & 19.29 & 18.49 & 55.06 & 52.80 & -4.64 & -12.22 \\
\hline $\begin{array}{l}\text { 4-Nitrophenol - } \\
\text { Pentachlorophenol }\end{array}$ & 3.26 & 3.31 & 9.62 & 9.67 & -1.88 & -6.11 \\
\hline
\end{tabular}

phenol, 2,4-dimethylphenol and 2,4-dichlorophenol for these phases (Table 7), it can be concluded that 2-nitrophenol seems the most sensitive reagent to the polarity of various stationary phases. So it would be an appropriate indicator to assay the polarity of these phases. In comparison with commercial stationary phases, P-LCuSt exhibited somewhat lower polarity than 5\% blended diphenyl-polysiloxane. In other respect, the substituents $\mathrm{Cl}-, \mathrm{NH}_{2}-$ or $\mathrm{NO}_{2}-$ confer on phenol greater polarity, methyl substituents lead to less polar property. The mutual interactions between the solute and stationary phase will also dependent upon the functional groups on different substitution position.

\subsubsection{Ligand exchange}

Nitro groups and chlorine atoms, both as do alkyl substituents increase the retention of phenols on a $\mathrm{C}_{18}$-silica bonded packing [19]. A similar manner was found in Petronio's work with iron-loaded resin for the separation of phenols [20]. They claimed that the differences in sorption strengths can not be explained by differences in formation constants. In this work, however, chlorophenol and nitrophenol form metal complexes weaker than that of phenol just as that expected from the differences in formation constants. Namely, 2-nitrophenol, the electron- withdrawing substituents decrease the electron density of the phenolic oxygen, and a more pronounced effect was found for the electron-releasing, methylgroup in the para-substitution than that in the orthoposition. With regard to the gas-phase basicity of the donating element, the order of the retention strengths, phenol $\left(180^{\circ} \mathrm{C}\right)>2$-nitrophenol $\left(214^{\circ} \mathrm{C}\right)$; $p$-methylphenol $\left(202^{\circ} \mathrm{C}\right)>m$-methylphenol $\left(203^{\circ} \mathrm{C}\right)$; and 2,4-dichlorophenol $\quad\left(210^{\circ} \mathrm{C}\right)>2,4,6$-trimethylphenol $\left(220^{\circ} \mathrm{C}\right)>2,4$-dimethylphenol $\left(211^{\circ} \mathrm{C}\right)$ gave convincing examples of the ligand exchange mechanism.

\subsubsection{Molecular geometry}

The separations based upon vapor pressure, polarity interaction and ligand exchange, were found more or less enhanced by the stationary phase having liquid-crystalline properties, which yield shape selectivity. $m$-Methylphenol $\left(203^{\circ} \mathrm{C}\right)$ eluted before $p$-methylphenol $\left(202^{\circ} \mathrm{C}\right)$ might be due to the fact that the trans isomer is inserted more easily in the ordered liquid crystal structure. 3-Methyl-4-chlorophenol $(\mathrm{L} / \mathrm{B}, 1.110)$ exhibited a longer retention time than 4-bromophenol (L/B, 1.458), even though their boiling points are the same, $235^{\circ} \mathrm{C}$. Solutes most similar to the disc type ordered environment will interact more strongly than those are structurally 

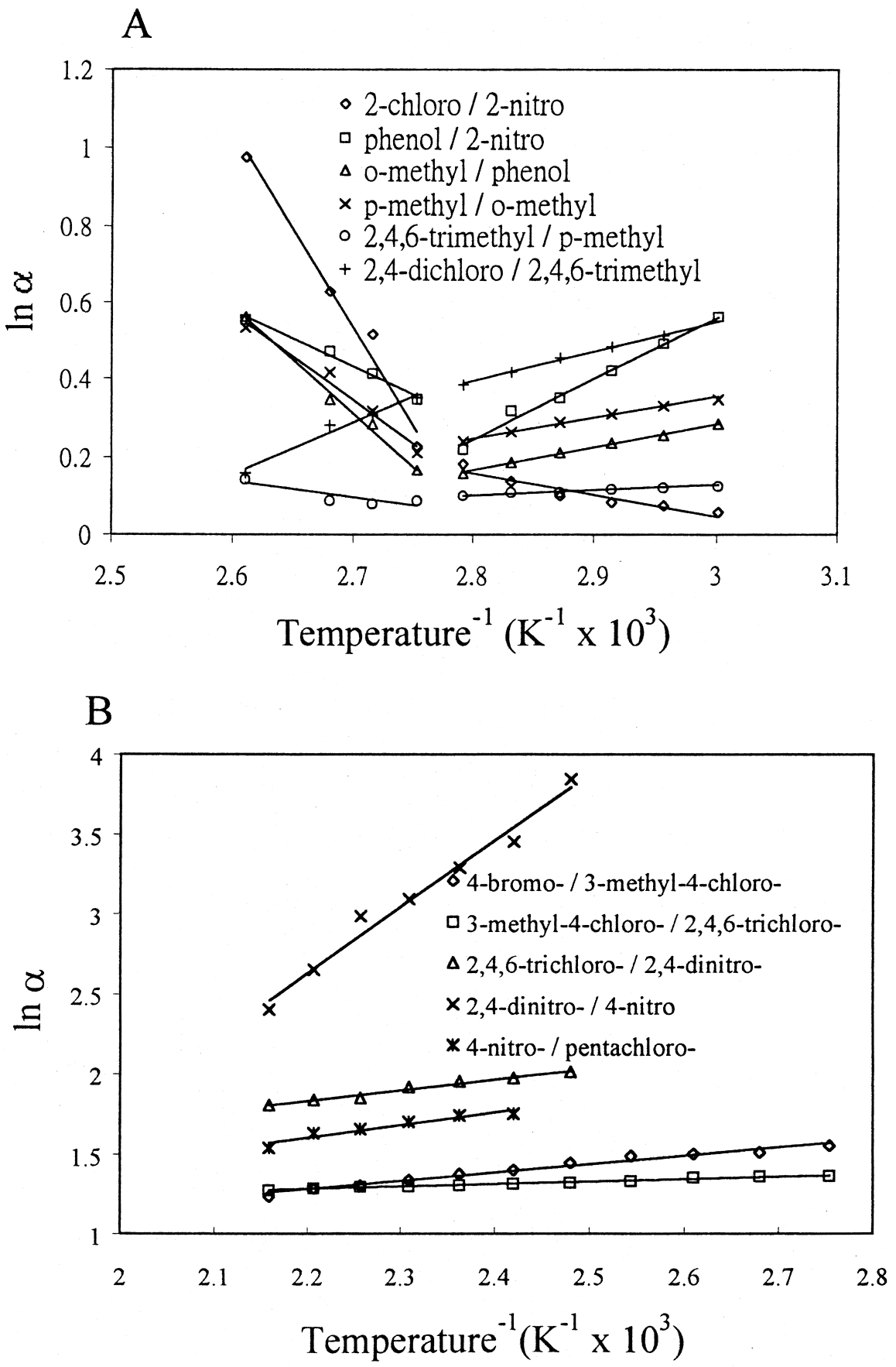

Fig. 9. Experimental dependences $\ln \alpha$ versus reciprocal absolute temperature for substituted phenols on a novel wall-coated capillary column. 
Table 7

Comparison the elution order of phenols separated with commercial stationary phases and wall-coated P-LCuSt capillary columns

\begin{tabular}{llllll}
\hline Stationary phase & \multicolumn{2}{l}{ Elution order } & & & \\
\cline { 2 - 6 } & 2-Chlorophenol & Phenol & 2-Nitrophenol & 2,4-Dimethylphenol & 2,4-Dichlorophenol \\
\hline Rtx-5 & 2 & 1 & 3 & 4 & 5 \\
Rtx-50 $^{\text {b }}$ & 2 & 1 & 4 & 3 & 5 \\
Rtx-200 $^{\text {c }}$ & 2 & 1 & 5 & 3 & 4 \\
P-LCuSt & 1 & 3 & 2 & 4 & 5 \\
\hline
\end{tabular}

${ }^{\mathrm{a}} 5 \%$ Diphenyl-95\% dimethyl polysiloxane; from Restek (Bellefonte, PA, USA).

${ }^{\mathrm{b}} 50 \%$ Phenyl-50\% methyl polysiloxane; from Restek (Bellefonte, PA, USA).

${ }^{\mathrm{c}}$ Trifluoropropylmethyl polysiloxane; from Restek (Bellefonte, PA, USA).

${ }^{\mathrm{d}}$ Prepared in this work.

Table 8

Calibration data for the determination of phenols ${ }^{\mathrm{a}}$

\begin{tabular}{|c|c|c|c|c|c|}
\hline Compound & $\begin{array}{l}\text { Linear range } \\
\left(\mu \mathrm{g} \mathrm{ml}^{-1}\right)\end{array}$ & Slope & $\begin{array}{l}\text { Linearity } \\
\text { Intercept }\end{array}$ & $r$ & $\begin{array}{l}\text { Detection limit } \\
\text { (ng) }\end{array}$ \\
\hline 2-Chlorophenol & $10-1000$ & 66.66 & -0.97 & 0.9993 & 13.1 \\
\hline 2-Nitrophenol & $20-1000$ & 22.55 & -131.55 & 0.9993 & 30.1 \\
\hline Phenol & $10-1000$ & 71.77 & -252.68 & 0.9995 & 6.5 \\
\hline$o$-Methylphenol & $10-1000$ & 82.65 & -174.44 & 0.9997 & 17.2 \\
\hline$m$-Methylphenol & $10-1000$ & 81.09 & 186.61 & 0.9995 & 16.5 \\
\hline$p$-Methylphenol & $10-1000$ & 80.53 & 434.75 & 0.9992 & 16.4 \\
\hline 2,4-Dimethylphenol & $10-1000$ & 98.46 & 480.82 & 0.9995 & 16.8 \\
\hline 2,4,6-Trimethylphenol & $10-1000$ & 92.48 & -191.08 & 0.9993 & 15.2 \\
\hline 2,4-Dichlorophenol & $10-1000$ & 68.52 & 196.53 & 0.9994 & 7.4 \\
\hline 4-Bromophenol & $10-1000$ & 81.37 & 17.35 & 0.9994 & 17.6 \\
\hline 3-Methyl-4-chlorophenol & $10-1000$ & 98.17 & -161.44 & 0.9997 & 17.5 \\
\hline 2,4,6-Trichlorophenol & $10-1000$ & 74.48 & 198.29 & 0.9993 & 17.5 \\
\hline 2,4-Dinitrophenol & $10-1000$ & 74.59 & -48.97 & 0.9993 & 17.0 \\
\hline 4-Nitrophenol & $25-1000$ & 16.35 & 30.24 & 0.9986 & 50.2 \\
\hline Pentachlorophenol & $25-1000$ & 16.93 & -104.63 & 0.9987 & 48.3 \\
\hline
\end{tabular}

${ }^{\mathrm{a}}$ Conditions as Fig. 7D.

incompatible. The result does correspond to those of Witkiewicz et al. [10].

\section{Linear calibration range}

The calibration graphs of peak area against the quantity of each analyte were found to be linear over the concentration range studied, i.e. 10-1000 $\mu \mathrm{g}$ $\mathrm{ml}^{-1}$ for an injection volume of $1 \mu \mathrm{l}$ of the phenols listed in Table 8. The correlation coefficients for all the calibration graphs were between 0.9986 and $0.9997(n=7)$. The three times standard deviation of seven measurements of the lowest peak that could be detected is less than $20 \mathrm{ng}$ except for 2-nitrophenol, 4-nitrophenol and 2,4,6-trichlorophenol.

\section{Conclusions}

A disc-like metallomesogenic polymer has been introduced for the preparation of wall-coated capillary columns. These phases possess unique selectivity for phenolic compounds. They were well separated without derivatization. Full explanation of the separation mechanism is not easy. However, not only shape selectivity, but also ligand exchange play an important role. In comparison with the performance of rod-like metallomesogens in a previous paper [8], a distinct phenomenon was observed that the mesophase of copper-carboxylate provided a better coordination center for the separation of substituted phenols, especially for pairs of 4-bromophenol/3methyl-4-chlorophenol/2,4,6-trichlorophenol. The 
established methods combined with supercritical fluid extraction has been applied for the determination of phenols in soil. It will be reported in another paper. For deeper insight into the retention mechanism, it was advisable to separate more different compounds with these phases.

\section{Acknowledgements}

The authors thank the National Science Council of the Republic of China, Taiwan, for financial support.

\section{References}

[1] D. Demus, J. Goodby, G.W. Gray, H.W. Spiess, V. Vill, in: Handbook of Liquid Crystals, Fundamentals, Vol. 1, VCH, Weinheim, Germany, 1998, p. 857.

[2] K. Fujimura, M. Kitanaka, H. Takayanagi, T. Ando, Anal. Chem. 54 (1982) 918.

[3] H. Takayanagi, M. Hashizume, K. Fujimura, T. Ando, J. Chromatogr. 350 (1985) 63.

[4] H. Takayanagi, M. Akita, K. Fujimura, T. Ando, J. Chromatogr. 350 (1985) 75.

[5] P. Berdague, F. Perez, J. Courtieu, J.P. Bayle, O. Abdelhadi, S. Guermouche, M.H. Guermouche, J. High Resolut. Chromatogr. 18 (1995) 304.
[6] C.C. Hu, C.Y. Liu, Anal. Chim. Acta 332 (1996) 23.

[7] C.Y. Liu, C.C. Hu, C.L. Yang, J. Chromatogr. A 773 (1997) 199.

[8] C.Y. Liu, C.C. Hu, J.L. Chen, K.T. Liu, Anal. Chim. Acta 384 (1999) 51.

[9] P. Mubmann, K. Levsen, W. Radeck, Fresenius' J. Anal. Chem. 348 (1994) 654.

[10] Z. Witkiewicz, J. Szulc, R. Dabrowski, J. Chromatogr. 315 (1984) 145.

[11] Z. Witkiewicz, B. Goca, J. Chromatogr. 402 (1987) 73.

[12] A. Kraus, U. Schumann, G. Kraus, B. Kohne, K. Praefcke, J. Chromatogr. 609 (1992) 277.

[13] A.M. Giroud-Godquin, J.C. Marchon, D. Guillon, A. Skoulios, J. Phys. Lett. 45 (1984) L681.

[14] H. Abied, D. Guillon, A. Skoulios, P. Weber, A.M. GiroudGodquin, J.C. Marchon, Liq. Cryst. 2 (1987) 269.

[15] A.M. Giroud-Godquin, P.M. Maitlis, Angew. Chem. Int. Ed. Engl. 30 (1991) 375.

[16] D.E. Martire, A. Nikolic, K.L. Vasanth, J. Chromatogr. 178 (1979) 401.

[17] E.F. Meyer, J. Chem. Educ. 50 (1973) 191.

[18] S. Ghodbane, G.A. Oweimreen, D.E. Martire, J. Chromatogr. 556 (1991) 317.

[19] V.A. Davankov, J.D. Navratil, H.F. Walton, in: Ligand Exchange Chromatography, CRC Press, Boca Raton, Florida, 1988, p. 190.

[20] B.M. Petronio, A. Lagana, G.D. Andrea, Talanta 31 (1984) 357. 